\title{
Level of adoption of West Virginia agriculture teachers' usage of internet-based educational technology in the classroom
}

Travis Daniel Veach

West Virginia University, tdveach@mix.wvu.edu

Follow this and additional works at: https://researchrepository.wvu.edu/etd

Part of the Vocational Education Commons

\section{Recommended Citation}

Veach, Travis Daniel, "Level of adoption of West Virginia agriculture teachers' usage of internet-based educational technology in the classroom" (2021). Graduate Theses, Dissertations, and Problem Reports. 8016.

https://researchrepository.wvu.edu/etd/8016

This Thesis is protected by copyright and/or related rights. It has been brought to you by the The Research Repository @ WVU with permission from the rights-holder(s). You are free to use this Thesis in any way that is permitted by the copyright and related rights legislation that applies to your use. For other uses you must obtain permission from the rights-holder(s) directly, unless additional rights are indicated by a Creative Commons license in the record and/ or on the work itself. This Thesis has been accepted for inclusion in WVU Graduate Theses, Dissertations, and Problem Reports collection by an authorized administrator of The Research Repository @ WVU. For more information, please contact researchrepository@mail.wvu.edu. 
Level of adoption of West Virginia agriculture teachers' usage of internet-based educational technology in the classroom

Travis Daniel Veach

Thesis submitted to the Davis College of Agriculture, Natural Resources, and Design

at West Virginia University in partial fulfillment of the requirements

for the degree of

Master of Science

in

Agricultural and Extension Education

Rachel Hendrix, Ph.D., Chair

Jessica Blythe, Ph.D.

Joey Blackburn, Ph.D.

School of Design and Community Development

Morgantown, West Virginia

2021

Keywords: Adoption, Internet-based Educational Technology, Education

Copyright 2021 Travis Daniel Veach 


\begin{abstract}
Level of adoption of West Virginia agriculture teachers' usage of internet-based educational technology in the classroom
\end{abstract}

\author{
Travis Veach
}

The purpose of this study was to determine the level of adoption of West Virginia agricultural educators' usage of internet-based educational technology for instruction. The population for this study included 103 educators during the 2020-2021 school year. The study yielded thirty-two responses from the population. Respondents indicated they use internet-based educational technology for their classroom instruction. Respondents indicated they use internet-based educational technology in a variety of different ways for instruction. Respondents adopted internet-based educational technology at varying degrees depending on the technology, some respondents being early adopters, and others later adopters. 


\section{Acknowledgements}

I would like to thank my committee, Dr. Hendrix, Dr. Blythe, and Dr. Blackburn. Dr. Hendrix, thank you for all your support through this process, you have helped me grow as a writer and an educator through my time in graduate school. Dr. Blythe, thank you for your support through my undergraduate studies and now as a graduate student, you have helped shape me into a better educator and have helped to prepare me for the classroom. Dr. Blackburn, thank you for agreeing to serve as my outside committee member, your valuable insight has shaped me into a better research and a critical thinker.

I would like to thank my family for their constant love and support throughout this process. Mom and dad, your constant words of encouragement, always being available for a phone call when needed, or a weekend trip home have helped me through this process. I love you both and could not have made it through these last few years without you all.

To my colleagues and best friends Madi, Cole, Katie and Kindra: we made it! Although we went different paths, we were able to accomplish the goal we set for ourselves after being in undergrad together. Thank you all for the support over these past two years, I can't wait to see what we all accomplish in our careers. 


\section{TABLE OF CONTENTS}

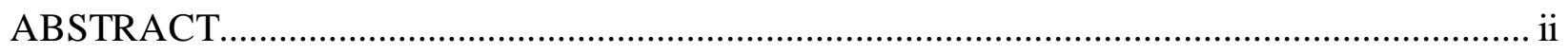

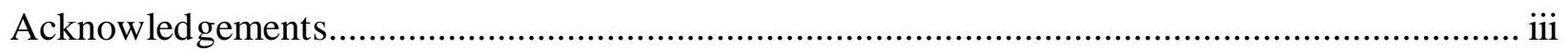

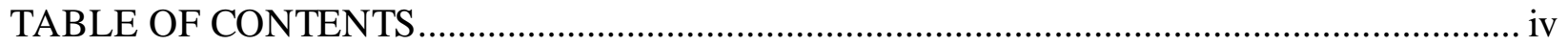

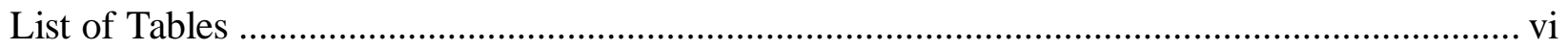

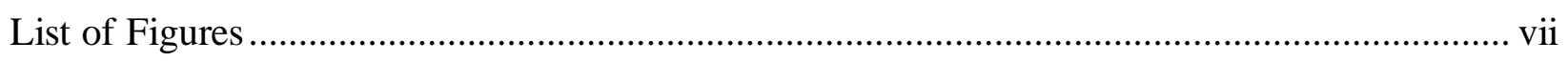

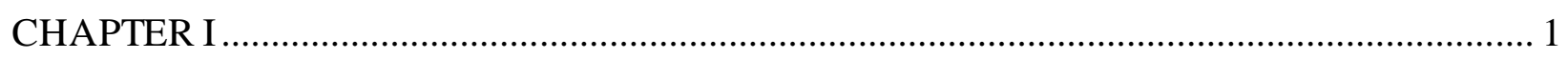

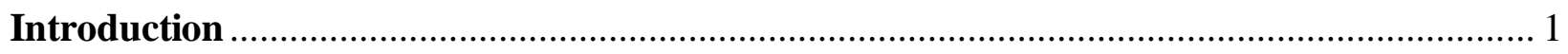

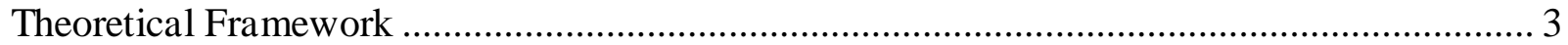

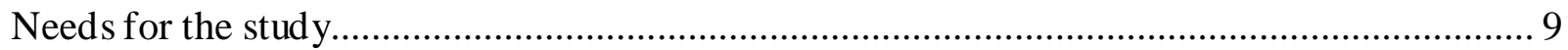

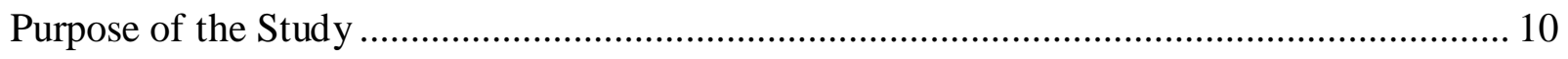

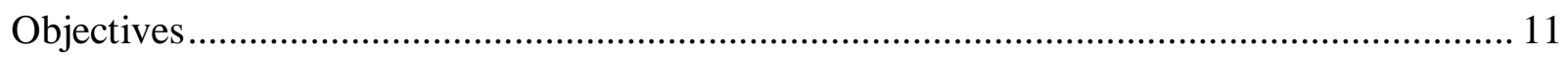

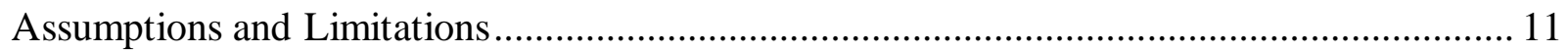

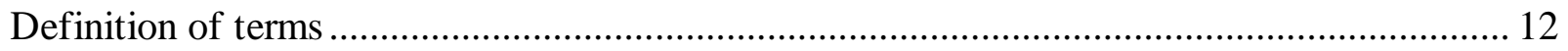

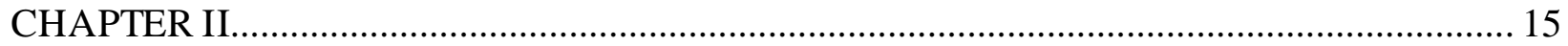

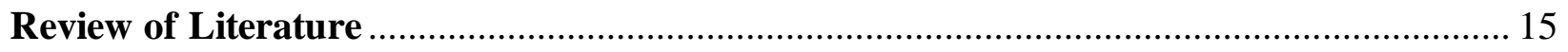

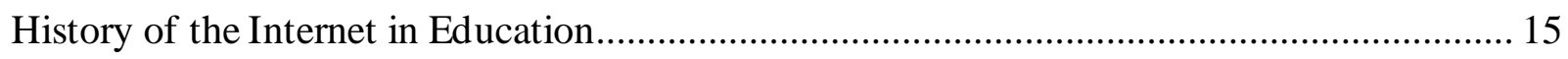

Barriers to implementing educational technology in the classroom ................................... 15

Internet-based educational technology in the classroom.................................................. 16

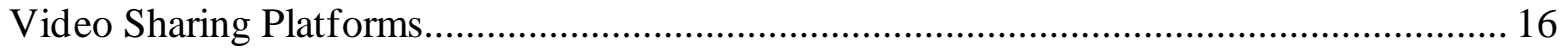

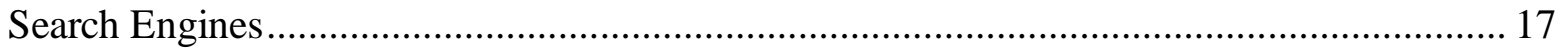

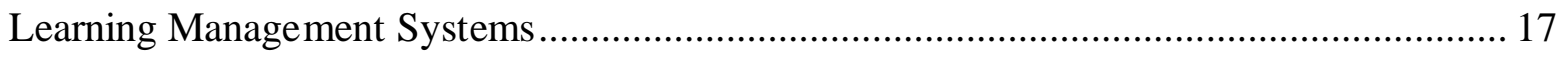

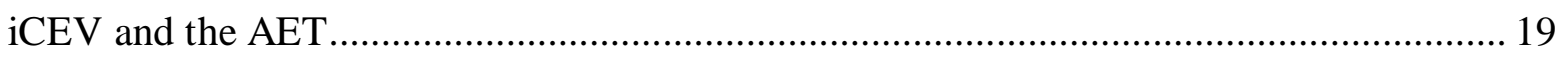

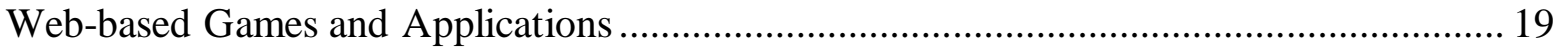

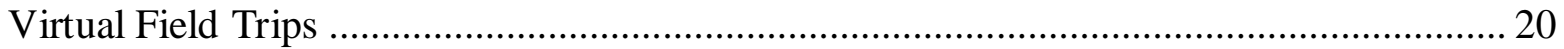

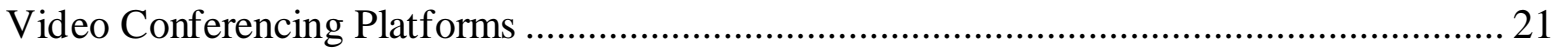

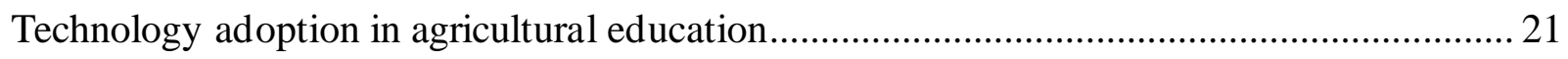

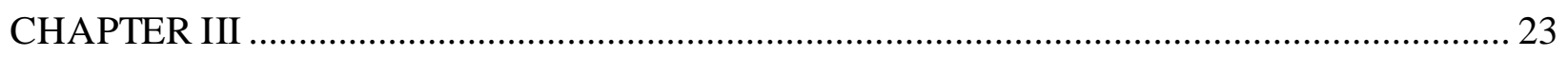

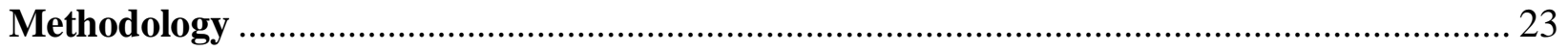

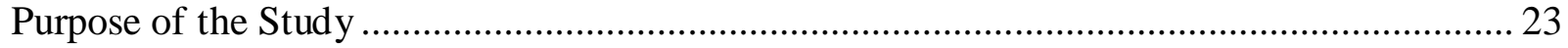

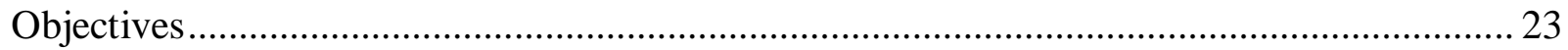

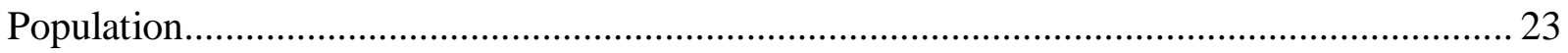




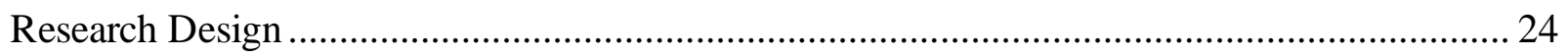

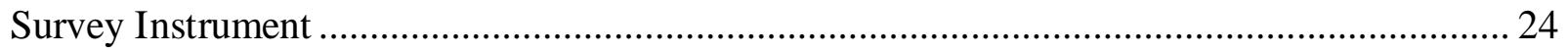

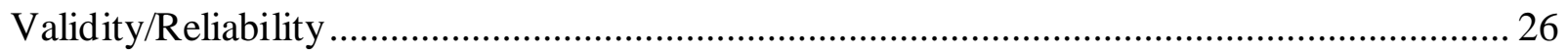

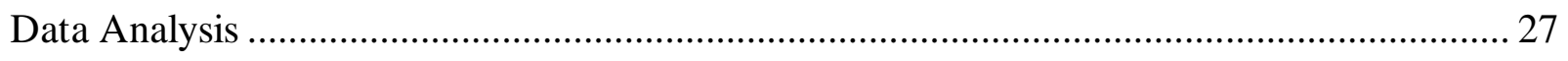

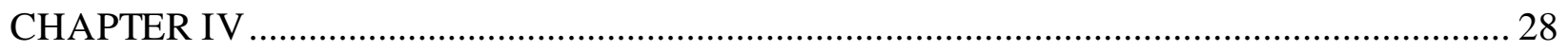

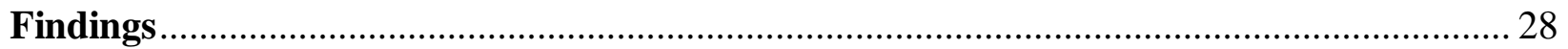

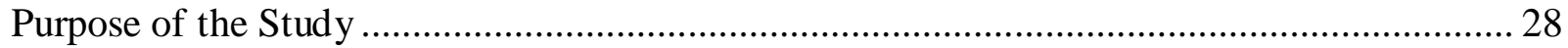

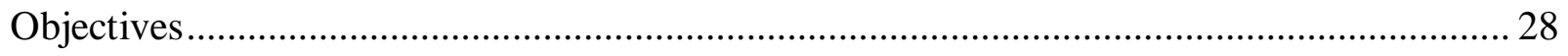

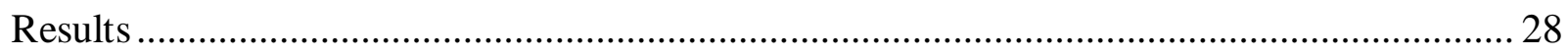

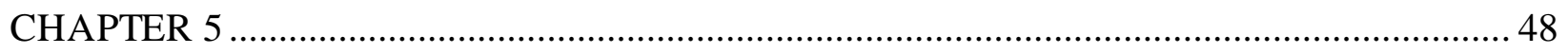

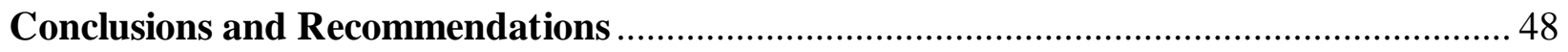

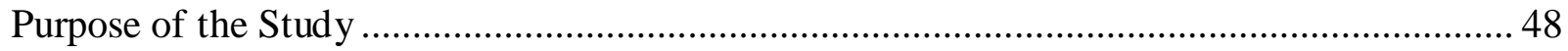

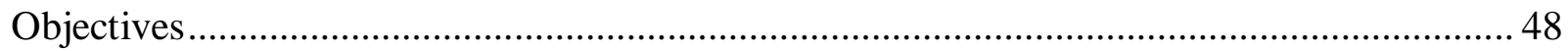

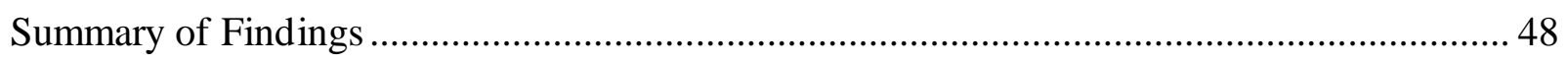

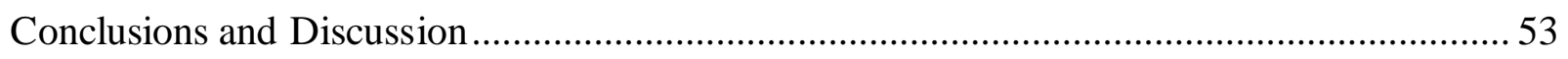

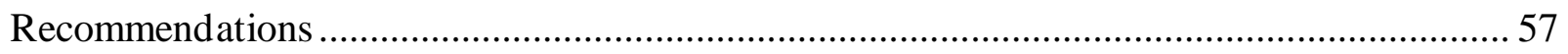

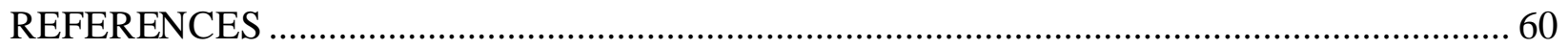

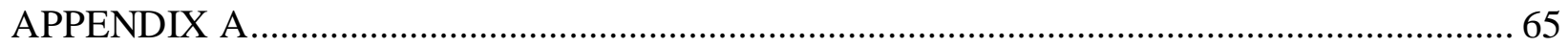

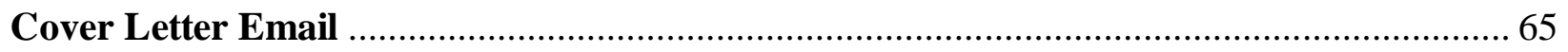

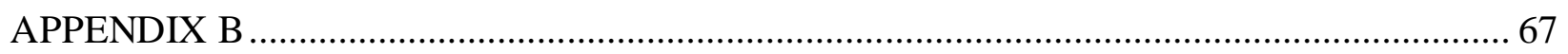

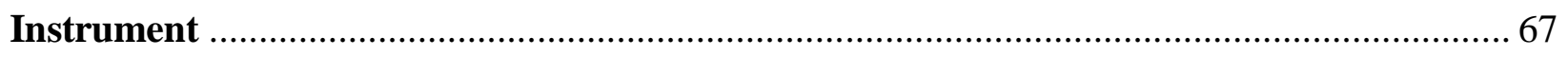

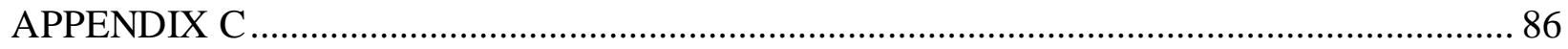

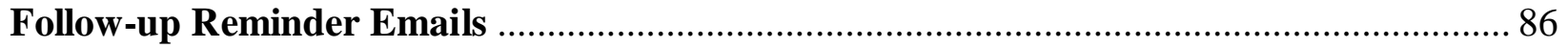

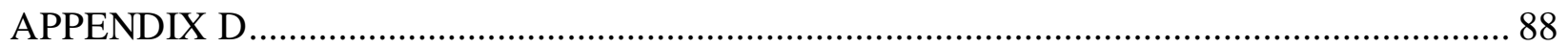

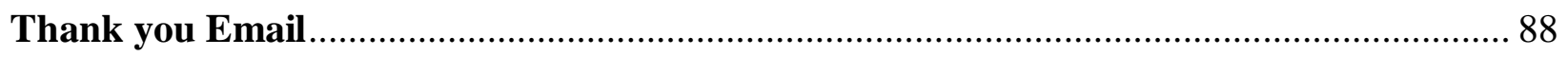




\section{List of Tables}

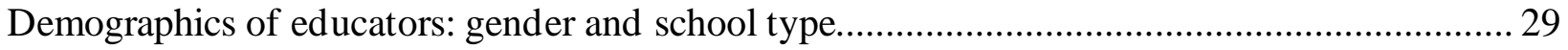

Demographics of educators: clas sfication of school district and teachers in program ................ 30

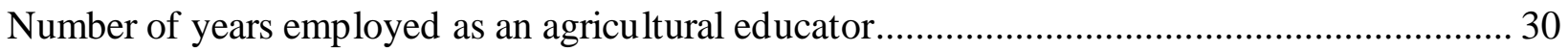

Accessibility of resources for internet-based educational technologly in West Virginia

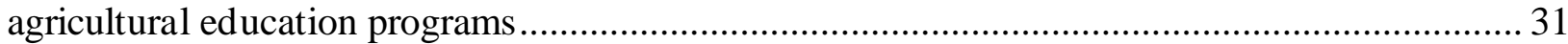

How often educators use internet-based educational technology for instruction ...................... 33

How educators use video sharing platforms for instruction ................................................ 34

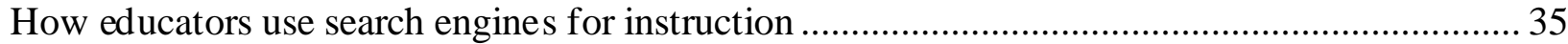

How educators use learning management systems for instruction ........................................ 35

How educators use web-based games and apps for instruction ......................................... 36

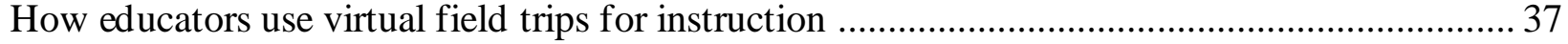

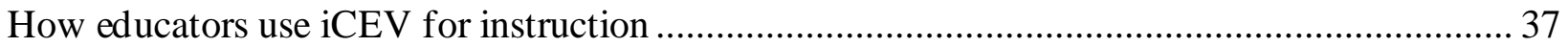

Averages of relative advantage relating to internet-based educational technology .................... 38

Averages of compatability relating to internet-based educational technology .......................... 39

Averages of complexity relating to internet-based educational technology .............................. 40

Averages of trialability relating to internet-based educational technology .............................. 40

Averages of observability relating to internet-based educational technology .......................... 41

Ranking of how educators best became aware of internet-based educational technology ........... 43

Decision to adopt internet-based educational technology for classroom instruction .................. 44

Barriers to implementing internet-based educational technology for classroom instruction ....... 44

How educators best learned how to use internet-based educational technology ....................... 45

Perceived adopter categories of internet-based educational technology among agricultural educators 


\section{List of Figures}

Figure 1: Adopter categorization on the basis of innovativeness (Rogers, 2003) ...................... 5 


\section{CHAPTER I}

\section{Introduction}

Education has changed since computers were first used in classrooms throughout the country. Information is now more readily available to the student and teacher for learning in the $21^{\text {st }}$ Century through use of technology in education (U.S Department of Education, n.d.). The computer, or other devices teachers or students have at their disposal allow new information to be obtained in a setting which otherwise may have not been available to them through a textbook. Integrating computer technology into the classroom has shown a positive shift in pedagogical involvement in preparing students for a digitized world (Yadav \& Berges, 2019). With the advancement of computer technology and the ability to research and find results in an instant, it is vital to ask: are teachers utilizing these tools in their classroom?

The United State Department of Education defines internet-based educational technology as "technology resources that are used for classroom instruction via usage of the Internet which help to promote learning and experiences for $21^{\text {st }}$ Century learning" (n.d.). Teachers can potentially utilize many forms of internet-based educational technology within their classrooms if they have access to necessary resources like computers, tablets, smartphones, or internet connections. Examples of internet-based educational technology are software such as Microsoft Office (Office 365), search engines such as Yahoo! and Google, web-based games such as Kahoot! for review of classroom materials, and virtual field trips, which give students the opportunity to learn about different fields in their respective courses without leaving the classroom. Online programs for education are becoming increasingly popular as students begin to shift away from paper and textbooks and towards online or digital formats of the same concept (a digital copy of a textbook as opposed to hardcopy) (Kim \& Bonk, 2006). The recent changes in education due to the novel coronavirus (COVID-19) have created a push towards using online 
resources for instruction as students are working remotely. Educators have had to adapt their lessons to better fit an online form of learning for student retention (Iivari et al., 2020).

Agricultural education provides opportunities for students to lead successful careers in the agricultural industry. The core of agricultural education is based on a three-circle model: classroom and laboratory instruction, Supervised Agricultural Experience (SAE) programs, and the FFA. Classroom instruction, which provides learning opportunities within school and laboratory settings, utilizes different teaching styles and methods to students through a variety of different topics relating to agriculture, such as animal and plant sciences, mechanics, forestry, and many more. SAE programs provide students with personalized, career-related learning experiences that utilize skills developed in the classroom. The FFA, which compliments classroom and SAE accomplishments, allows students to gain leadership opportunities gain knowled ge about different careers in the industry, and the opportunity to compete in areas of agriculture in which they show interest (Phipps \& Osborne, 1988).

Internet-based educational technology in agricultural education can provide students with skillsets that they can use for future careers in the agricultural industry. Williams et al. (2014) reported North Carolina agricultural education students using technology in many different areas such as research, communication, and problem-solving. Coley et al. (2015) identified different ways that agriculture educators used technology for instruction and found that many were using the internet for research, as well as word processing and presentation programs. The study also noted that not having access to the necessary resources to use technology was an indicator on their decision to adopt or reject it for instruction (Coley et al., 2015).

Ramsey and Edwards (2011) identified skills students were expected to learn while completing SAE experiences, such as building resumes, calculating formulas, and web design. 
These were a few of the skills students could learn while in SAE programs using this computer technology. Students in agricultural education classes in West Virginia have access to the Agricultural Experience Tracker (AET) an online resource which allows for students to keep accurate records of expenditures as well as awards and experiences achieved while in the classroom, work completed during their SAE programs, and participation in the FFA.

\section{Theoretical Framework}

Rogers (2003) defines diffusion as "the process in which an innovation is communicated through certain channels over time among the members of a social system” (p. 5). As this definition describes, the innovation itself, communication channels, time, and social systems are the four key components of the diffusion of innovations. Innovations are defined an idea, practice, or object that are perceived as new by an individual or other unit of adoption (Rogers, 2003, p.12). Rogers (2003) identifies two types of communication channels. The first type of channel involves mass communication sources that use one person to reach many potential adopters. Examples of this type of channel include social media platforms, news outlets, radio stations, and newspapers. The other type of communication channel is an interpersonal channel, which allows for face-to-face interactions with two or more individuals. Interpersonal channels are more effective in persuading potential adopters of innovations (Rogers, 2003). Time as a diffusion element examines the innovation-decision process itself, and measures adopters according to when they adopt or reject the innovation (Rogers, 2003). The last element of the diffusion process is the social system, which consists of units in a system working towards a common goal or objective, through members such as opinion leaders and change agents Opinion leaders are those members in a social system who help lead the diffusion process internally, 
whereas change agents are external to the system and push towards adoption of new innovations (Rogers, 2003).

The innovation-decision process is the series of observations and decisions an individual makes when interacting with an innovation. It involves a person gaining knowledge of the innovation, forming attitudes about it, and making decisions about its adoption and use. Rogers describes this process as being different for various members in the social system through the innovations-decision period. This period is the length of time it takes for an individual to pass through the innovation-decision process (Rogers, 2003).

Rogers (2003) discusses the five stages of the innovation-decision process, as well as factors regarding each stage that influence potential adopters. The first stage, knowledge, occurs when an individual is first introduced to an innovation. Persuasion is the second stage. This is when potential adopters begin to develop attitudes, either positive or negative, about the innovation. Attitudes are based on an individual's own needs, and while influential, do not lead directly or indirectly towards adoption or rejection of the specific innovation (Rogers, 2003, p. 176). Stage three is the decision stage and is the time where potential adopters either adopt or reject the innovation (Rogers, 2003, p. 177). Stage four is the implementation stage where potential adopters put the innovation into practice. This stage is critical for adoption and is seen as the "last" stage of the process, as individuals will have either decided to adopt or reject the innovation at this point. The fifth stage of the innovation-decision process is the confirmation stage, where the individual looks for support of their decision to implement - or not implement the innovation (Rogers, 2003, p. 189).

Rogers (2003) identifies shortcomings within diffusion research, the most serious being the pro-innovation bias. Pro-innovation bias is "the implication in diffusion research that an 
innovation should be diffused and adopted by all members of a social system, that it should be diffused more rapidly, and that the innovation should neither be re-invented or rejected" (Rogers, 2003, p. 106). The pro-innovation bias focuses more on the successes of an innovation, and not on the failures (Rogers, 2003). Rogers (2003) suggests that in the future, a different kind of diffusion study is needed to remove the pro-innovation bias.

Another shortcoming with diffusion research that Rogers defines is the concept of individual-blame bias. Individual-blame is "the tendency to hold an individual responsible for his or her problems, rather than the system of which the individual is a part" (Rogers, 2003, p. 119). Rogers (2003) identifies why individual-blame may occur in diffusion research, some reasoning being that communication channels provide inadequate information about innovations, and failure to contact less educated members of a social system. Late adopters and laggards are often individually blamed for not adopting an innovation and for being later in adopting than others in the social system (Rogers, 2003, p. 121).

Rogers (2003) divides individuals undergoing the innovation-decision process into five categories. He defines adopter categories as "the classification of members of a social system on the basis of innovativeness" (p. 22). Classifications of adopters include innovators, early adopters, early majority, late majority, and laggards. In each adopter category, members of the social system are separated by characteristics that help determine their adoption of innovations. These categories are represented by a bell curve depending on the rate of adoption depicted in Figure 1.

\section{Figure 1}

Adopter Categorization on the Basis of Innovativeness 


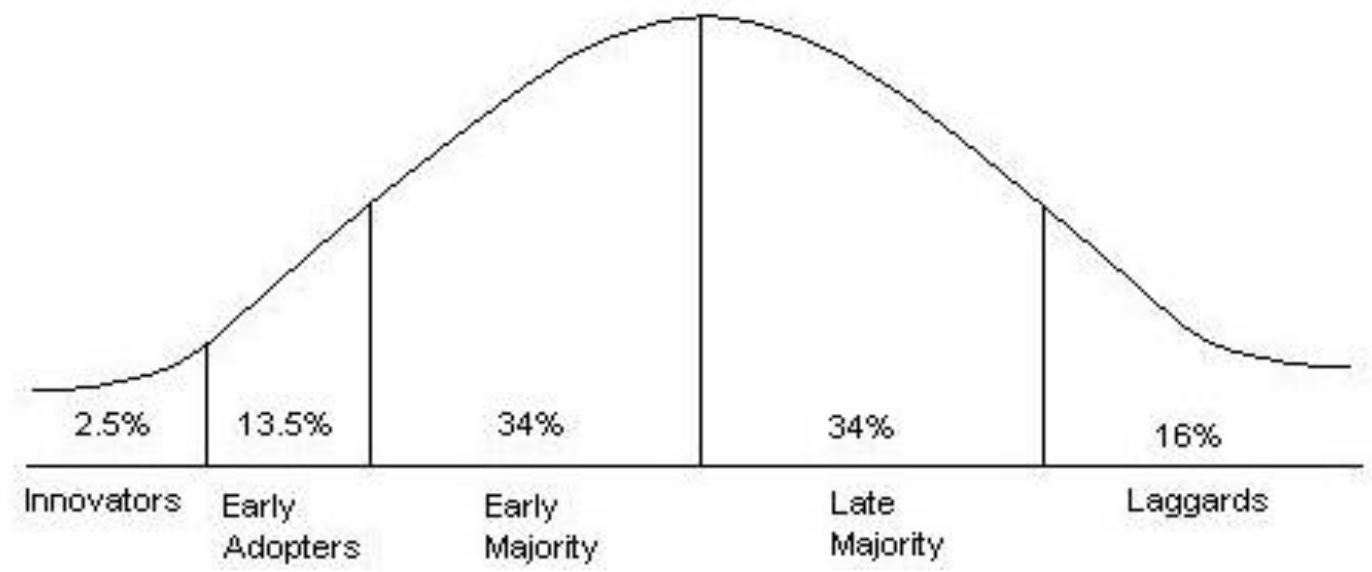

Note. Bell curve representing percentage of adopters among the five categories (Rogers, 2003).

Innovators are those members of the social system who are venturesome and willing to experience new ideas. These members may experience backfire if innovations are not as beneficial as planned and will typically have stable finances to cover losses if they occur. It is also important that the innovator understand complexities of any technology they are adopting if they are the first to use it and no resources are available for assistance. Innovators play an important role in the diffusion process by introducing their communities and social systems to an idea or innovation, and, serving as a gatekeeper among the system (Rogers, 2003).

Early adopters have more of a leadership role in terms of the system than innovators, as innovators typically interact with members outside of the social system. Members in the social system come to early adopters with questions on advice and information regarding the innovation, so it is essential these adopters have a clear understanding of the innovation. Change agents work with this category to speed the diffusion process. Early adopters adopt an idea and provide subjective information regarding the idea through interpersonal channels in the system (Rogers, 2003, p. 283). 
Members of the early majority have a good interaction among the members of the social system, but typically do not take leadership roles in the innovation process. These members are deliberate in their adoption of new innovations and want to be sure that it will benefit them. Early majority adopt new innovations right before the average member. The members in this category make up one-third of all adopters (Rogers, 2003, p. 284).

Like early majority, the late majority make up one-third of all members in the system. These members adopt new innovations after the average members in the group. Late majority are skeptical of new ideas and want to see the innovation will have benefits for them before they decide to adopt or reject. Members in late majority are influenced by economic factors as well as pressures from members in the social system (Rogers, 2003, p. 284).

The last adopter category are laggards and these members are the last in the social system to adopt an innovation. Laggards are isolated from many members of the social system and tend to only interact with those members who share their same values. Members in this social system make decisions based on what was done in the past. Laggards are typically suspicious of innovations and want to see the innovation will not fail before they make the decision to adopt as they may have limited resources (Rogers, 2003).

Rogers (2003) defined the rate of adoption as "the relative speed with which an innovation is adopted by members of a social system" (p. 221). Attributes of an innovation include five characteristics: relative advantage, compatibility, complexity, trialability, and observability. Rogers identifies five predictor variables which help to determine rate of adoption of an innovation: perceived attributes of an innovation, the innovation-type decision (optional, collective, or authority), communication channels (mass media or interpersonal), social system (the norms or network interconnectedness), and change agents. Rogers (2003) explained that the 
most variance, $49-87 \%$, of the rate of adoption can be explained within the perceived attributes of the innovation (p. 221).

Relative advantage is commonly referred to as the most important predictor in determining the rate of adoption of an innovation. Rogers (2003) defines relative advantage as "the degree to which an innovation is perceived as being better than the idea it supersedes" (p. 229). New innovations are adopted more rapidly if potential adopters perceive the innovation is more advantageous than the old. Depending on the type of innovation, change agents potentially struggle if potential adopters are unable to see the relative advantage immediately (Rogers, 2003, p. 233).

Compatibility is the degree to which an innovation is perceived as consistent with existing values, past experiences, and needs of potential adopters (Rogers, 2003, p. 240). An important aspect with compatibility is that uncertainty about an innovation is alleviated. Change agents working in the social system identify needs of its members and help to find compatible innovations for members to adopt (Rogers, 2003, p. 246). The compatibility of an innovation, as perceived by members of a social system, is positively related to its rate of adoption (Rogers, 2003, p. 249).

Complexity is "the degree to which an innovation is perceived as difficult to understand and use" (Rogers, 2003,pg. 16). This characteristic is primarily suggesting that the harder something is to grasp, the longer that it will take to be adopted than less complicated innovations. Trialability is "the degree to which an innovation may be experimented with on a limited basis" (Rogers, 2003, pg. 16). If someone can try an innovation on a limited basis rather than the entire thing at once, the innovation is adopted at a faster rate than if the innovation was presented all at once. Observability is "the degree to which the results of an innovation are visible to others" 
(Rogers, 2003, pg. 16). If someone can see the results of an innovation, then they are better equipped to make an informed decision regarding adoption.

There are three main types of the innovation-decision process. The first is optional innovation-decision, which allows for members to adopt or reject an innovation based on their own merits, and not from the decision of those in a social system. The second is collective innovation-decision, in which individuals choose to adopt or reject innovations based solely on a consensus of all members in a social system. The last type is authority innovative decision, where few people in a social system make all the decisions relating to adoption or rejection of an innovation.

The other predictor variables relating to the rate of adoption of innovations are communication channels, the nature of the social system, and change agent's effect on the population. Communication channels influence rate of adoption depending on how many members of the social system have already adopted the innovation and can be measured through the innovation-decision process. Change agents also play a key role in the rate of adoption of innovations by making potential adopters aware of the innovation (Rogers, 2003, p. 170).

\section{Needs for the study}

With educational technology relating to the internet becoming more relevant in the classroom, it is important to consider whether such tools are accessible to agriculture educators in West Virginia, and if so, how they are being adopted and used in the classroom. The accessibility of the internet has the potential to be important to a teacher's adoption of using educational technology in their classrooms, because if they do not have access to reliable internet via ethernet or wireless access, they may not use the technology for instruction as it may prove 
more of a nuisance than a reliable tool. The Federal Communications Commission (FCC) (2014) identifies broadband internet as "a minimum of $25 \mathrm{MB}$ download speeds and $3 \mathrm{MB}$ upload speeds" (para. 2). In many rural areas, the access to reliable internet is limited, and dial-up internet may be the only option available. Broadband internet is provided through a variety of different facets, whereas dial-up is provided through phone lines, primarily in rural areas where broadband internet is not as easily accessible (FCC, 2014).

Both the state of West Virginia and its schools are largely classified as rural (United States Department of Education, 2013). According to the United States Department of Education (2013), 43.9\% of schools in West Virginia were considered rural, $21.6 \%$ of schools were in towns, $20.2 \%$ of schools in suburban areas, and $14.3 \%$ of schools were in urban areas. With many of the state's classrooms being in rural areas and in small towns, teachers and students in these schools may not have access to reliable broadband internet to use internet-based educational technology in the classroom. Another issue is the access to necessary tools such as computers or other devices that can access the internet for classroom instruction or to assign work outside of the classroom associated with this technology. There is a significant need for the study because currently there is no data which reflect agricultural educators' level of adoption using internet-based educational technology in their classrooms in WV. This study has the potential to identify what online-based technologies agricultural educators are using for instruction and identify areas for improvement related to their adoption of the technologies. It could also provide them with necessary training to utilize them, such as online training or professional development workshops to prepare them for education in the $21^{\text {st }}$ century.

\section{Purpose of the Study}


The purpose of the study is to determine the level of adoption of West Virginia agricultural educators' usage of internet-based educational technology for instruction.

\section{Objectives}

1. Describe accessibility of internet access and resources in classrooms for internet-based educational technology.

2. Describe the frequency of internet-based educational technology used in agricultural education classrooms.

3. Identify barrier(s) agricultural educators have regarding implementing internet-based educational technology in their classrooms.

4. Determine perceptions of West Virginia agricultural educators related to the perceived attributes of internet-based educational technology.

5. Describe level of adoption of West Virginia agricultural educators' usage of internetbased educational technology.

\section{Assumptions and Limitations}

The following are assumptions for this study:

1. Participants in the study completed the survey honestly and to the best of their ability.

2. Participants in the study use internet-based educational technology in some capacity for classroom instruction.

The following are limitations for this study:

1. Participants self-reported data for the study. Self-reported data can raise issues regarding honesty, accuracy of responses, response bias, and completeness of instrument 
2. There is no current research relating to technology adoption among WV agricultural educators.

\section{Definition of terms}

Adopter Categories- classifications of the members of social system on the basis of their innovativeness (Rogers, 2003, p. 473).

Agricultural Education- Instruction that is related to agricultural sciences, forestry, and natural resources. Comprised of three components, classroom/laboratory instruction, experiential learning, and leadership development (NAAE, 2020).

Agriculture Educator- an educator who teaches agricultural education at the middle school or secondary level (Research Defined).

Applications- software downloaded to devices that can be used to perform specific purposes (Researcher Defined).

Compatibility- the degree to which an innovation is perceived as consistent with existing values, past experiences, and needs of potential adopters (Rogers, 2003, p. 473).

Complexity- the degree to which an innovation is perceived as relatively difficult to understand and use (Rogers, 2003, p. 474).

Hybrid Learning- an environment where students attend in-person classes as well as virtually (Boyarsky, 2020).

Innovation- an idea, practice, or object that is perceived as new by an individual or other unit of adoption (Rogers, 2003, p. 475). 
Internet-based Educational Technology- technology resources that are used for classroom instruction via usage of the Internet which help to promote learning and experiences for $21^{\text {st }}$ Century learning (United States Department of Education, n.d.).

Observability- the degree to which the results of an innovation are visible to observe (Rogers, 2003, p. 475).

Rate of Adoption- the relative speed with which an innovation is adopted by members of a social system (Rogers, 2003, p. 476).

Relative Advantage- the degree to which an innovation is better than the idea it supersedes (Rogers, 2003, p. 476).

Remote Learning- an environment where the teacher and student are not present in a traditional classroom setting and learning occurs in various online formats (Ray, 2020).

Search Engine- software accessed on the Internet that search a database of information according to user's input (Computer Hope, 2020).

Trialability- the degree to which an innovation may be experimented with on a limited basis (Rogers, 2003, p. 476).

Video Conferencing Platforms- allow users in different locations the ability to hold face-to-face meetings virtually (Kagan, 2019).

Video Sharing Platform- resources that educators have in the classroom to watch and share videos for instructional material (Researcher Defined).

Virtual Field Trip- an interactive web-based experience that educators can use for instruction without leaving the classroom (Researcher Defined). 
Web-based Games- Games used for education that can be used for introduction to topics, supplemental class material, and review of course topics (Researcher Defined). 


\section{CHAPTER II \\ Review of Literature}

\section{History of the Internet in Education}

The concept of the modern computer was first developed in the late 1940's. In the early 1960's, research began on networking computers from multiple locations and funds were allocated to the US Department of Defense to build a prototype network. The "forerunner" of the internet, ARPANET, was established. One of the main functions of ARPANET was the ability to send emails across an established network (Mowery \& Simcoe, 2002, p. 1371-1372).

Networking in the United States began with ARPANET as it was the source of networking between three universities in the country, spanning across the continent. As the internet grew, more universities began to adopt the software and be added to the network to share research (Mowery \& Simcoe, 2002, p. 1385). ARPANET (now known as the internet) was strengthened by TCP/IP (Transmission Control Protocol/Internet Protocol). The purpose of these protocols is to help determine how information is sent and received over the internet. These protocols are still in use today. The mid 1990's saw a shift in policy enacted to allow public schools to gain access to the internet and by 1998, most of the schools in the United States were connected (Levin \& Arafeh, 2002, p. 9). Schools have progressed with their usage of internetbased technologies through the years, and recently with the pandemic, many schools have switched to a full or hybrid online learning format (Kaden, 2020, p. 1).

\section{Barriers to implementing educational technology in the classroom}

Barriers towards technology integration are defined as any factor (external and internal) that prevent or restrict the use of specific technology by the teacher in the classroom (Becta, 2003). To integrate internet-based technology in the classroom, access to the resources needed to 
use it and barriers impacting integration must be identified (Williams et al., 2014). Williams et al. (2014) found that costs of implementing technology, time to develop lessons with the technology, and a lack of resources for students serve as moderate barriers in agricultural classrooms (p. 10). Kotrlik and Redmann (2009) identified seven barriers educators may have toward s integrating technology in their classrooms: (a) availability of technology for number of students, (b) availability of technical support to effectively use instructional technology in the teaching/learning process, (c) enough time to develop lessons that use technology, (d) schedule enough time for students to use the internet, computers, or other technology in the teaching/learning process, (e) availability of effective instructional material for courses taught, (f) ability to integrate technology in the teaching/learning process, and (g) administrative support for integration of technology in the teaching/learning process. The adoption of educational technology increases as barriers toward integration are eliminated (Kotrlik \& Redmann, 2009).

\section{Internet-based educational technology in the classroom}

\section{Video Sharing Platforms}

YouTube was first launched in 2005 as a resource for people to share short videos over the internet and has expanded drastically since its launch. YouTube has many uses such as entertainment, advertisement, as well as "how-to" videos which can be used for educational purposes (Terantino, 2011, p. 10). It is estimated that every minute, there are up to ten hours of content uploaded to the site for its users to view (Kaplan \& Haenlein, 2010). YouTube offers a subsection to their website YouTube EDU which allows them to access educational videos that can be used as supplemental material in classes. Teachers are also able to create their own channels which allows for teachers to upload videos and create playlists for their students (Nast, 
n.d.). The site can be used as a tool for $21^{\text {st }}$ Century learners and can be used for supplemental material in the classroom (Jones \& Cuthrell, 2011, p. 83).

Another video sharing platform that educators have access to is TeacherTube. Like YouTube, TeacherTube strives to "provide an online community for sharing instructional videos" (TeacherTube, 2020). Through the website, educators can join content related groups to share and collaborate information for instruction. One key difference between YouTube and TeacherTube is that educators can skip through amateur instructional videos posted on YouTube (Burke \& Snyder, 2008).

\section{Search Engines}

Search engines are software that search the internet based on keywords that are typed into search bars and search known databases for relevant information the user is looking for. Google's search algorithm, PageRank, bases a search on three factors: incoming links, outcoming links, and the rank of incoming links according to existing PageRank ratings based on relevancy (Langville \& Meyer, 2011). Since its introduction in the 1990's, search engines have become more sophisticated and tailored as more "user-friendly." The most common search engines in the United States are Google, Yahoo!, and Bing, with Google representing 91\% of total usage among the three (Seymour et al., 2011). Science educators in Utah report that using search engines in their classrooms for research purposes has benefited themselves in finding new information for classroom resources, as well as giving students the opportunity to search for topics in the related field s that interest them (Recker, Dorward, \& Nelson, 2004, p. 98).

\section{Learning Management Systems}


Learning management systems or LMS are a web-based software that consists of electronic tools such as email, discussion boards, and places to upload and grade assignments (Gautreau, 2011, p. 4). Schoology is an example of an LMS which offers some software from Microsoft and Google, while also creating their own software for classroom integration (Schoology, 2018). Schoology allows teachers to manage all aspects of their classroom within the LMS and connect with teachers anywhere. Alias \& Zainuddin (2005) identified benefits that LMS have for both student and teacher, those being organization of class materials, extra resources for both student and teacher, and enhancement of learning how to use technology (p. 29).

Microsoft Office 365 has different packages depending on what the user needs: business or education. In education, Office 365 provides students and educators with many features that have potential to make working on documents, collaboration, and meeting virtually easier than in past years. Office 365 offers a "cloud", meaning whatever the user has access to, they are able to access their files from any device, as files are saved in a data center and not on a local device (Carutasu \& Pirnau, 2017). Users can also download Microsoft Office directly to their devices and continue working if they do not have internet connection. Office 365 has gained popularity due to its low maintenance of being able to fix errors remotely as opposed to having to be onsite, downloading new software as it becomes available, and inexpensive storage options (Grysiuk, 2018, p. 21).

Google Workspace (formally known as Google Suite) is like Office 365 and offers users similar features, with the Google brand. Users may access features with Google Workspace and use them with the web browser Google Chrome for ease of access. Kakoulli-Constantinou (2018) reported that the software associated with Google Suite was user-friendly and well received by 
both student and teacher. The study also reported that Google Classroom and Google Drive (software associated with Google Workspace) were great resources allowing information to be saved securely online (Kakoulli-Constantinou, 2018).

\section{iCEV and the AET}

The Agricultural Experience Tracker (AET) was designed for students in agricultural education courses to track records while working on various SAE projects as well as rewards earned while in the classroom or through FFA activities. The AET system was first developed in 2007 and has grown since its launch, with over 400,000 students using the resource (AET, n.d.). The purpose of the AET was to update the current record keeping system that was being used by agricultural teachers. The site contains resources for students and teachers ranging from lesson plans, trainings on how to manage the site, and how to best use the AET while in the classroom (Our Story, 2021).

iCEV is an online curriculum platform that educators in Career and Technical Education (CTE) programs have access to, one of those curricula being agricultural sciences (iCEV, 2020). Using iCEV, educators have access to numerous pre-built and customizable lesson plans to use for their classroom instruction. Easterly \& Simpson (2020), conducted a study among Utah agricultural educators to see how they interacted with curricular resources, like iCEV. The study showed that educators used iCEV resources with a relatively low frequency $(n=7)$ and educators reported they used the curriculum monthly (Easterly \& Simpson, 2020, p. 36-37).

\section{Web-based Games and Applications}

With the introduction of the internet into education, web-based games have been introduced as supplemental material to students in the classroom. Web-based games used in 
education help create a learning environment that allows students to engage in an activity that they find enjoyable and allow for information to be presented to students in another format and give students more opportunities to interact with their teachers, peers, and the content (McDonald \& Hannfin, 2003; Licorish et al., 2018). Kahoot! is an example of a web-based game that can be used for numerous functions in the classroom: activating strategies at the beginning of class, class discussion and surveys, as well as quiz or exam review. One of the positives of Kahoot! is it does not require students to download an app or create an account; they only need access to a device that can access the internet. Plump \& Larosa (2017) found that Kahoot! was easy for teachers to use and did not require prior training. Web-based games are accessible through web browsers.

Applications, or Apps, are another online game format an educator can use for instruction. Apps are like web-based games, but can be downloaded to the device that students are using, eliminating the need for a web browser. Kahoot! is a web-based game accessible either through web browsers or through an app. Apps have other uses in education besides the use of web-based games like tracking student progress and organization of material. The use of mobile technology with apps allow for students to engage in activities they are accustomed with (Domingo \& Garganté, 2016).

\section{Virtual Field Trips}

Field trips used in secondary education allow students to experience classroom topics in a real-world setting, adding realism and relevancy to the topic. Virtual field trips provide students with this opportunity in a virtual setting with the capability of a computer. Educators incorporate virtual field trips into their courses via the internet, saving money and time which is normally associated with traditional field trips (Tuthill \& Klemm, 2002). Virtual field trips allow for 
students to essentially travel long distances and interact with experts in the field without ever having to leave the classroom in asynchronous or interactive synchronous formats (Zanetis, 2010). Educators may use this resource of a virtual field trip prior to visiting the site to give students an introduction to the topic as well as after to assess their knowledge of what they observed (Klemm \& Tuthill, 2003).

\section{Video Conferencing Platforms}

With students either working remotely or in a hybrid setting due to COVID-19, video conferencing platforms have been used for education. One example of these platforms is Zoom, which allows for collaborative discussion, allowing users to meet and interact remotely, and secure recording of meetings (Zoom Video Communications Inc., 2016). Office 365 and Google Workspace also offer video conferencing platforms in Microsoft Teams and Google Meet. Archibald et al. (2019) reported users of Zoom enjoyed using the platform due to it being user friendly, and convenient to meet with people from anywhere, but a disadvantage of the platform being difficulty connecting due to poor internet access and hardware being out of date (p. 4).

\section{Technology adoption in agricultural education}

Williams et al. (2014) examined factors influencing North Carolina agricultural educators' decisions to adopt technology into their classrooms. They found teachers chose to incorporate technology based off personal experience and through trial and error on their part. It was found teachers experience approximately 16 hours of professional development related to technology usage (Williams et al., 2014, pg. 5). Teachers agreed with the idea of integrating technology within their classrooms as it allowed students to be more creative and facilitated the exposure of new material in a different way (Williams et al., 2014, pg. 7). 
A study conducted in Louisiana looked at the availability of smartphone technology in the classroom, as well as the teacher's adoption towards using technology in the classroom (Smith et al., 2018). The study was looking for the usage of smartphone availability, but other technology resources such as computers were also collected as data. Teachers reported they enjoyed using technology in their classrooms for instruction and they experienced minimal barriers with using it. Although the study did not correlate directly to internet-based educational technology, the data showed most teachers use computers or other devices capable of accessing the internet in their classrooms for a multitude of lessons (Smith et al., 2018, p. 246).

Coley et al. (2015) examined technology adoption among agriculture teachers in Tennessee. Teachers were asked to describe their perceived level of technology adoption with sixty-six respondents reporting they are among the first to adopt new technologies as they come available and seventy-seven respondents stating they let others test new technologies before adoption (Coley, et al., 2015, p. 40). Teachers in Tennessee used the internet daily for classroom instruction, using resources such as internet browsers and classroom management systems. The study described costs of implementing new technologies as a moderate barrier, with time to develop lessons and availability of resources being minor barriers (Coley, et al., 2015). 


\section{CHAPTER III}

\section{Methodology}

\section{Purpose of the Study}

The purpose of the study is to determine the level of adoption of West Virginia agricultural educators' usage of internet-based educational technology for instruction.

\section{Objectives}

1. Describe accessibility of internet access and resources in classrooms for internet-based educational technology.

2. Describe the frequency of internet-based educational technology used in agricultural education classrooms.

3. Identify barrier(s) agricultural educators have regarding implementing internet-based educational technology in their classrooms.

4. Determine perceptions of West Virginia agricultural educators related to the perceived attributes of internet-based educational technology.

5. Describe level of adoption of West Virginia agricultural educators' usage of internetbased educational technology.

\section{Population}

The target population included West Virginia agriculture educators who were employed during the 2020-2021 academic school year $(N=103)$. This includes educators who are teaching in high schools, middle schools, and technical centers throughout the state. West Virginia agriculture educators are accessible via the West Virginia Department of Education with contact information including mailing addresses, email addresses, and phone numbers. This list of 
educators was gathered via an email group provided by the West Virginia Department of Education for the 2020-2021 school year.

\section{Research Design}

The design used for the study was descriptive survey research (Ary et al., 2014).

Descriptive research allows the researcher to organize, summarize, and describe observations (Ary et al., 2014). Educators were made aware of the survey and its intentions three days prior via email. Web-based surveys are the fastest growing surveying method currently in the United States, as well as throughout the world (Dillman et al., 2014). Dillman et al. (2014) identifies effective ways on introducing the target population to the survey to help increase participation by helping to ensure the respondents know the information they are providing is important (p. 20). The survey was administered via Qualtrics and accessible through web browsers on computers or laptops, or by mobile devices, although computers and laptops were designated as the preferred method to complete the survey due to formatting of Likert-style questions.

Response rates were expected to be high for multiple reasons. First, the data collected from the survey will be used to benefit agriculture educators in West Virginia in the future with regards to internet-based educational technology. Second, measures were taken to increase response rates following recommend ations for a one-month survey (Dillman et al., 2018). Additionally, with a small target population $(N=103)$ it is important to have higher response rates to ensure the data is valid.

\section{Survey Instrument}

The survey instrument used a census for data collection. The census was used to collect data regarding the demographics of each educator, the frequency of their usage of internet-based 
educational technology, as well as questions that determine their level of adoption and the barriers which may arise while using internet-based educational technology for instruction. Additional information gathered included the perceptions of perceived attributes relating to the internet-based educational technology. A census was the best method for this study, as the population encompassed 103 educators and random sampling would not allow for reliable data collection. There was no cost to administering this census as it was completed via the online survey website Qualtrics. The instrument was not distributed to agriculture educators until after acquiring approval from WVU Internal Review Board (IRB).

The instrument consisted of four primary sections, which were used to answer the problem being addressed, as well as the objectives being measured. Effective questioning was utilized to ensure responses were accurate to meeting the researchers' objectives. Four introductory questions were used to determine if respondents have access to reliable internet and to technology resources in their classrooms for student and educator, and if they use internetbased educational technology for classroom instruction. The first section of the instrument addressed their frequency of the technology usage for instruction with options being never, rarely, occasionally, often, and always. Educators were then asked what they use each internetbased educational technology for classroom instruction. The second section of the instrument utilized a 5-point Likert-type Scale addressing the perceived characteristics of the innovation, the distinctions ranging from strongly disagree, disagree, neither agree nor disagree, agree, and strongly agree. Multiple-choice responses and a ranking question were also used in this section and were used to determine adoption and barriers to implementing the technology in the classroom. 
The third section of the instrument asked questions relating to the adopter categories of the internet-based educational technology in classroom instruction. These questions were used to identify the perceived adopter categories and level of adoption of the educators for each of the internet-based educational technologies. The final section of the instrument contained questions that were used to collect respondent demographics. Questions in this section included information such as length of teaching career, school type (high school, middle school, technical center), the number of teachers in each program and the classification of their school district.

\section{Validity/Reliability}

Validity of an instrument is essential to make sure the instrument and the results are accurate. For validity to be established, the instrument must measure what it is intended to measure. To ensure validity of the instrument, the researcher sent the survey to a panel of experts prior to administration of the survey to the population. The members of this panel include Dr. Rachel Hendrix, Dr. Jessica Blythe, and Dr. Joey Blackburn.

A pilot study was performed prior to data collection of the target population, in order to determine the reliability of the survey, to determine Cronbach's alpha $(\alpha)$ of internal consistency, and address any changes to the structure that need to be made to avoid nonresponse error. An acceptable range of Cronbach's alpha is .70 to .95 (Tavakol \& Dennick, 2011). Changes were to be made promptly to avoid errors with responses and questions may need to be changed to ensure questions being asked to provide accurate answers (Dillman et al., 2014, p. 6). The pilot study was sent to selected educators in agriculture education who were not part of the target population and have similar experiences in education like WV educators, the pilot group for this study included teachers in Mississippi. The pilot study consisted of twelve respondents. 
The relative advantage subscale consisted of four items $(\alpha=.89)$, the compatibility subscale consisted of three items $(\alpha=.76)$, and the complexity subscale consisted of two items $(\alpha$ $=.71)$. The trialability subscale consisted of two items $(\alpha=.77)$, and the observability subscale consisted of two items $(\alpha=.73)$. The barriers to implementing internet-based educational technology subscale consisted of five items $(\alpha=.70)$. Initially, the subscale relating to how respondents best learned how to use internet-based educational technology consisted of six items, however an item was removed to maintain consistency of the subscale $(\alpha=.70)$.

\section{Data Analysis}

Data was analyzed using IBM® SPSS® 27.0 for Windows. For each statistical test, the level of significance was set at a priori at $\alpha<.05$. Descriptive statistical analyses appropriate for scales of measurement were performed on the data, which included measures of central tendency (mean, median, and mode) and variability (frequencies and standard deviation.) Results of the analyzes were represented as frequencies and percentages, as well as the mean, median, and mode in table and narrative form.

\section{Early and Late Respondents}

Respondents were divided into two groups based on the dates of their responses. Those who responded before the first deadline were considered "early respondents" and those who responded after the second deadline were considered "late respondents." Recommendations were based on Lind ner et al. (2001) findings for assessing nonresponse. An independent t-test was conducted to compare early and late responders on "years employed as an agricultural teacher," "classification of school district," "number of teachers in program," and "the school type." The results of the t-test showed no significant difference between the groups. 


\section{CHAPTER IV}

\section{Findings}

\section{Purpose of the Study}

The purpose of the study was to determine the level of adoption of West Virginia agricultural educators' usage of internet-based educational technology for instruction.

\section{Objectives}

1. Describe accessibility of internet access and resources in classrooms for internet-based educational technology.

2. Describe the frequency of internet-based educational technology used in agricultural education classrooms.

3. Identify barrier(s) agricultural educators have regarding implementing internet-based educational technology in their classrooms.

4. Determine perceptions of West Virginia agricultural educators related to the perceived attributes of internet-based educational technology.

5. Describe level of adoption of West Virginia agricultural educators' usage of internetbased educational technology.

\section{Results}

The population consisted of all West Virginia agricultural educators who were employed during the 2020-2021 academic school year $(N=103)$. Respondents were reached through an email list provided by the state department. The final response rate from the population was 32 respondents, which is $31 \%$ percent of the total population. $31 \%$ of the population is an acceptable representation of the entire population (Ary et al., 2014). 
The population was asked to identify their demographical information. Fifty-six percent $(f=18)$ identified as male, $41 \%(f=13)$ identified as female, $3 \%(f=1)$ selected prefer not to answer (see Table 1). When asked to identify the type of school they were employed in; $81 \%(f=$ 26) responded with high school, $13 \%(f=4)$ responded with middle school, and $6 \%(f=2)$ responded with both high school and middle school.

\section{Table 1}

Demographics of educators: gender and school type

\section{$f$}

Gender

Male

Female

Prefer not to answer

Total

School Type

High school

Middle school

Technical center

Both High school and Middle school
18

13

1

32

26

4

0

2

32
$\%$

56.30

40.60

3.10

100.00

81.30

12.50

.00

6.30

Total 100.00

Respondents were asked the classification of their school district (see Table 2). Of those responding, 28\% (f=9) selected rural, 50\% (f=16) selected town, 9\% $(f=3)$ selected suburban, and $13 \%(f=4)$ selected urban. Respondents were asked how many teachers were in their program. $50 \%(f=16)$ selected one teacher, 25\% $(f=8)$ selected two teachers, $19 \%(f=6)$ selected three teachers, and $6 \%(f=2)$ selected four teachers. 
Table 2

Demographics of educators: classification of school district and teachers in program

\begin{tabular}{lcc}
\hline & $f$ & $\%$ \\
\hline Classification & & \\
Rural & 9 & 28.10 \\
Town & 16 & 50.00 \\
Suburban & 3 & 9.40 \\
Urban & 4 & 12.50 \\
& & \\
Total & 32 & 100.00 \\
& & \\
Teachers in program & & \\
One teacher & 16 & 50.00 \\
Two teachers & 8 & 25.00 \\
Three teachers & 6 & 18.70 \\
Four teachers & 2 & 6.30 \\
& & \\
Total & 32 & 100.00 \\
\hline
\end{tabular}

Additionally, respondents were asked how many years they had been an agriculture educator as of the 2020-2021 school year (see Table 3). The average number of years spent teaching agricultural education was $14.63(S D=10.20)$.

Table 3

Number of years employed as an agricultural educator

\begin{tabular}{lcc}
\hline & $M$ & $S D$ \\
\hline Years & & \\
\hline
\end{tabular}

Respondents were asked if they had Internet access for classroom instruction (see Table 4). Of those responding, $97 \%(f=31)$ had access to the Internet for classroom instruction and $3 \%$ 
$(f=1)$ do not have access to the Internet for classroom instruction. Respondents were asked if they use internet-based educational technology for classroom instruction. Of those responding, $100 \%(f=32)$ use internet-based educational technology for classroom instruction. Respondents were asked if they have access to resources to use internet-based educational technology. Of those responding, 97\% $(f=31)$ indicated they do have access to resources to use internet-based educational technology and 3\% $(f=1)$ indicated they do not have access to resources to use internet-based educational technology. Respondents were asked if their students have access to resources to use internet-based educational technology. Of those responding, $100 \%(f=32)$ indicated their students do have access to resources to use internet-based educational technology.

\section{Table 4}

Accessibility of resources for internet-based educational technology in West Virginia agricultural education programs

\begin{tabular}{|c|c|c|c|c|}
\hline & \multicolumn{2}{|c|}{ Yes } & \multicolumn{2}{|c|}{ No } \\
\hline & $f$ & $\%$ & $f$ & $\%$ \\
\hline $\begin{array}{l}\text { Educators who have Internet access for } \\
\text { classroom instruction }\end{array}$ & 31 & 96.90 & 1 & 3.10 \\
\hline $\begin{array}{l}\text { Educators who used internet-based educational technology for } \\
\text { instruction }\end{array}$ & 32 & 100.00 & 0 & .00 \\
\hline $\begin{array}{l}\text { Educators access to resources to use internet-based educational } \\
\text { technology }\end{array}$ & 31 & 96.90 & 1 & 3.10 \\
\hline $\begin{array}{l}\text { Student access to resources to use internet-based educational } \\
\text { technology }\end{array}$ & 32 & 100.00 & 0 & .00 \\
\hline
\end{tabular}

Respondents were asked how often they used different internet-based educational technology resources for instruction (see Table 5). Respondents used video sharing platforms; $13 \%(f=4)$ never use it, $22 \%(f=7)$ used it rarely, $19 \%(f=6)$ used it occasionally, $44 \%(f=14)$ used it often, and 3\% ( $f=1)$ used it always. When asked how often they use search engines; $3 \%$ 
$(f=1)$ used it rarely, 9\% $(f=3)$ used it occasionally, 56\% $(f=18)$ used it often, and $31 \%(f=10)$ used it always. When asked how often they used learning management systems; $3 \%(f=1)$ used it rarely, 9\% $(f=3)$ used it occasionally, 34\% $(f=11)$ used it often, and 53\% $(f=17)$ used it always.

Respondents were asked how often they used web-based games and apps; $13 \%(f=4)$ never used it, $41 \%(f=13)$ used it rarely, $31 \%(f=10)$ used it occasionally, $13 \%(f=4)$ used it often, and 3\% $(f=1)$ used it always. Respondents were asked to indicate how often they used virtual field trips; 9\% $(f=3)$ never used it, 41\% $(f=13)$ used it rarely, 47\% $(f=15)$ used it occasionally, and 3\% $(f=1)$ used it often. When asked how often they used video conferencing platforms; 3\% $(f=1)$ never used it, 3\% $(f=1)$ used it rarely, $28 \%(f=9)$ used it occasionally, $44 \%(f=14)$ used it often, and $22 \%(f=7)$ used it always. Respondents were asked how often they used the AET; $9 \%(f=3)$ never used it, 3\% $(f=1)$ used it rarely, 9\% $(f=3)$ used it occasionally, 34\% $(f=11)$ used it often, and 44\% $(f=14)$ used it always. When asked how often they used iCEV; $31 \%(f=10)$ never used it, $22 \%(f=7)$ used it rarely, $13 \%(f=4)$ used it occasionally, $22 \%(f=7)$ used it often, and $13 \%(f=4)$ used it always. 
Table 5

How often educators use internet-based educational technology for instruction

\begin{tabular}{|c|c|c|c|c|c|c|c|c|c|c|}
\hline & \multicolumn{2}{|c|}{ Never } & \multicolumn{2}{|c|}{ Rarely } & \multicolumn{2}{|c|}{ Occasionally } & \multicolumn{2}{|c|}{ Often } & \multicolumn{2}{|c|}{ Always } \\
\hline & $f$ & $\%$ & $f$ & $\%$ & $f$ & $\%$ & $f$ & $\%$ & $f$ & $\%$ \\
\hline Video sharing platforms & 4 & 12.50 & 7 & 21.90 & 6 & 18.70 & 14 & 43.80 & 1 & 3.10 \\
\hline Search engines & 0 & .00 & 1 & 3.10 & 3 & 9.40 & 18 & 56.30 & 10 & 31.30 \\
\hline $\begin{array}{l}\text { Learning Management } \\
\text { System }\end{array}$ & 0 & .00 & 1 & 3.10 & 3 & 9.40 & 11 & 34.40 & 17 & 53.10 \\
\hline Web-based games and Apps & 4 & 12.50 & 13 & 40.60 & 10 & 31.30 & 4 & 12.50 & 1 & 3.10 \\
\hline Virtual field trips & 3 & 9.40 & 13 & 40.60 & 15 & 46.90 & 1 & 3.10 & 0 & .00 \\
\hline $\begin{array}{l}\text { Video conferencing } \\
\text { platforms }\end{array}$ & 1 & 3.10 & 1 & 3.10 & 9 & 28.10 & 14 & 43.80 & 7 & 21.90 \\
\hline AET & 3 & 9.40 & 1 & 3.10 & 3 & 9.40 & 11 & 34.40 & 14 & 43.80 \\
\hline $\mathrm{iCEV}$ & 10 & 31.30 & 7 & 21.90 & 4 & 12.50 & 7 & 21.90 & 4 & 12.50 \\
\hline
\end{tabular}


Respondents were asked a question on how they use video sharing platforms for classroom instruction (see Table 6). When asked how they used video sharing platforms for classroom instruction; $75 \%(f=24)$ used it for introduction to a unit topic, $25 \%(f=8)$ used it for activating strategies, $66 \%(f=21)$ used it for lessons for the unit, 63\% $(f=20)$ used it for review of classroom material, $19 \%(f=6)$ used it for formative and summative assessment, and $6 \%(f=$ 2) do not use the technology for instruction.

Table 6

How educators use video sharing platforms for classroom instruction

\begin{tabular}{lcc}
\hline & $f$ & $\%$ \\
\hline Introduction to a unit topic & 24 & 75.00 \\
Activating Strategies & 8 & 25.00 \\
Lessons for the unit & 21 & 65.60 \\
Review of Classroom Material & 20 & 62.50 \\
Formative/Summative assessment & 6 & 18.80 \\
Educator does not use the technology & 2 & 6.30 \\
\hline
\end{tabular}

Respondents were asked a question on how they use search engines for classroom instruction (see Table 7). Respondents used search engines for classroom instruction; 53\% ( $f=$ 17) used it for introduction to a unit topic, $56 \%$ percent $(f=18)$ used it for activating strategies, $78 \%(f=25)$ used it for lessons for the unit, $50 \%(f=16)$ used it for review of classroom material, $19 \%(f=6)$ used it for formative and summative assessment, and $3 \%(f=1)$ do not use the technology for instruction. 


\section{Table 7}

How educators use search engines for classroom instruction

\begin{tabular}{lcc}
\hline & $f$ & $\%$ \\
\hline Introduction to a unit topic & 17 & 53.10 \\
Activating Strategies & 18 & 56.30 \\
Lessons for the unit & 25 & 78.10 \\
Review of Classroom Material & 16 & 50.00 \\
Formative/Summative assessment & 6 & 18.70 \\
Educator does not use the technology & 1 & 3.10 \\
\hline
\end{tabular}

Respondents were asked a question on how they use learning management systems for classroom instruction (see Table 8). Forty-four percent $(f=14)$ used it for introduction to a unit topic, 53\% $(f=17)$ used it for activating strategies, $78 \%(f=25)$ used it for lessons for the unit, $69 \%(f=22)$ used it for review of classroom material, and $72 \%(f=23)$ used it for formative and summative assessment.

\section{Table 8}

How educators use learning management systems for classroom instruction

\begin{tabular}{lcc}
\hline & $f$ & $\%$ \\
\hline Introduction to a unit topic & 14 & 43.80 \\
Activating Strategies & 17 & 53.10 \\
Lessons for the unit & 25 & 78.10 \\
Review of Classroom Material & 22 & 68.80 \\
& & 71.90
\end{tabular}


Respondents were asked a question on how they use web-based games and apps for classroom instruction (see Table 9). Nine percent $(f=3)$ used it for introduction to a unit topic, $31 \%(f=10)$ used it for activating strategies, $16 \%(f=5)$ used it for lessons for the unit, $47 \%(f=$ 15) used it for review of classroom material, $25 \%(f=8)$ used it for formative and summative assessment, and $28 \%(f=9)$ do not use the technology for instruction.

Table 9

How educators use web-based games and apps for classroom instruction

\begin{tabular}{lcc}
\hline & $f$ & $\%$ \\
\hline Introduction to a unit topic & 3 & 9.40 \\
Activating Strategies & 10 & 31.30 \\
Lessons for the unit & 5 & 15.60 \\
Review of Classroom Material & 15 & 46.90 \\
Formative/Summative assessment & 8 & 25.00 \\
Educator does not use the technology & 9 & 28.10 \\
\hline
\end{tabular}

Respondents were asked a question on how they use virtual field trips for classroom instruction (see Table 10). When asked how they used virtual field trips for classroom instruction; 38\% (f=12) used it for introduction to a unit topic, $19 \%(f=6)$ used it for activating strategies, 38\% ( $f=12)$ used it for lessons for the unit, $22 \%(f=7)$ used it for review of classroom material, $6 \%(f=2)$ used it for formative and summative assessment, and $28 \%(f=9)$ do not use the technology for instruction. 
Table 10

How educators use virtual field trips for classroom instruction

\begin{tabular}{lcc}
\hline & $f$ & $\%$ \\
\hline Introduction to a unit topic & 12 & 37.50 \\
Activating Strategies & 6 & 18.70 \\
Lessons for the unit & 12 & 37.50 \\
Review of Classroom Material & 7 & 21.90 \\
Formative/Summative assessment & 2 & 6.30 \\
Educator does not use the technology & 9 & 28.10 \\
\hline
\end{tabular}

Respondents were asked a question on how they use iCEV for classroom instruction (see Table 11). Thirty-one percent $(f=10)$ used it for introduction to a unit topic, $28 \%(f=9)$ used it for activating strategies, $56 \%(f=18)$ used it for lessons for the unit, $38 \%(f=12)$ used it for review of classroom material, $28 \%(f=9)$ used it for formative and summative assessment, and $38 \%(f=12)$ do not use the technology for instruction.

Table 11

How educators use iCEV for classroom instruction

\begin{tabular}{lcc}
\hline & $f$ & $\%$ \\
\hline Introduction to a unit topic & 10 & 31.30 \\
Activating Strategies & 9 & 28.10 \\
Lessons for the unit & 18 & 56.30 \\
Review of Classroom Material & 12 & 37.50 \\
Formative/Summative assessment & 9 & 28.10
\end{tabular}


Respondents were asked the degree to which they agreed or disagreed with statements relating to the relative advantage of internet-based educational technology with data being reported as means and standard deviation (see Table 12). When given the statement, "I use internet-based educational technology because it is cost efficient for instruction," the average was $3.56(S D=1.04)$. Respondents rated the statement, "I believe internet-based educational technology fosters positive learning experiences for students in my classes," the average was $3.72(S D=.92)$. Respondents rated the statement, "Internet-based educational technology is convenient to use for instruction," an average of $3.97(S D=.97)$. When given the statement, "Internet-based educational technology helps improve the quality of my work," the average was $3.78(S D=.98)$.

Table 12

Averages of relative advantage relating to internet-based educational technology

$M \quad S D$

Internet-based educational technology is

convenient to use for instruction

Internet-based educational technology

.98

helps improve the quality of my work

technology fosters positive learning experiences for students in my classes

I use internet-based educational technology because it is cost efficient for instruction

Note. $1.00-1.59=$ Strongly Disagree, $1.60-2.59=$ Disagree, $2.60-3.59=$ Neither Agree nor Disagree, $3.60-4.59=$ Agree, and $4.60-5.00=$ Strongly agree 
Respondents were asked the degree to which they agreed or disagreed with statements relating to the compatibility of internet-based educational technology with data being reported as means and standard deviation (see Table 13). When given the statement, "I am willing to incorporate new methods of teaching for instruction," the average was $4.47(S D=.51)$. Respondents were given the statement "I have support with adopting new internet-based educational technology for my instruction," the average was $4.13(S D=.91)$. Respondents rated the statement "Internet-based educational technology works well with my teaching style," the average was $3.81(S D=1.00)$.

Table 13

Averages of compatibility relating to internet-based educational technology

\begin{tabular}{lcc}
\hline & $M$ & $S D$ \\
\hline & & \\
$\begin{array}{l}\text { I am willing to incorporate new methods of } \\
\text { teaching for instruction }\end{array}$ & 4.47 & .51 \\
$\begin{array}{l}\text { I have support with adopting new internet-based } \\
\text { educational technology for my instruction }\end{array}$ & 4.13 & .91 \\
$\begin{array}{l}\text { Internet-based educational } \\
\text { technology works well with my } \\
\text { teaching style }\end{array}$ & & \\
\hline
\end{tabular}

Note. 1.00 - $1.59=$ Strongly Disagree, 1.60 - 2.59= Disagree, 2.60 - $3.59=$ Neither Agree nor Disagree, 3.60 - 4.59= Agree, and 4.60 - 5.00 = Strongly agree

Respondents were asked the degree to which they agreed or disagreed with statements relating to the complexity of internet-based educational technology with data being reported as means and standard deviation (see Table 14). Respondents were given the statement "I believe some internet-based educational technology is easier to use than others," the average was 4.13 
$(S D=.91)$. When given the statement, "I believe internet-based educational technology is difficult to use for instruction, the average was $2.56(S D=1.10)$.

Table 14

Averages of complexity relating to internet-based educational technology

$M$

4.13

2.56

I believe internet-based educational technology is difficult to use for instruction

technology is easier to use than others
$S D$

.91

Note $1.00-1.59=$ Strongly Disagree, $1.60-2.59=$ Disagree, $2.60-3.59=$ Neither Agree nor Disagree, 3.60 - $4.59=$ Agree, and 4.60 - 5.00 = Strongly agree

Respondents were asked the degree to which they agreed or disagreed with statements relating to the trialability of internet-based educational technology with the data being reported as means and standard deviation (see Table 15). Respondents were asked the statement, "I am willing to see help while testing out new internet-based educational technology for instruction" the average was $3.97(S D=.76)$ When given the statement, "I test internet-based educational technology before using them for my instruction, the average was $3.94(S D=1.01)$.

\section{Table 15}

Averages of trialability relating to internet-based educational technology

M

SD 
I am willing to seek help while testing out new internet-based educational

technology for instruction

I test internet-based educational technology

resources out before using them for instruction

Note. $1.00-1.59=$ Strongly Disagree, $1.60-2.59=$ Disagree, $2.60-3.59=$ Neither Agree nor Disagree, $3.60-4.59=$ Agree, and $4.60-5.00=$ Strongly agree

Respondents were asked the degree to which they agreed or disagreed with statements relating to the observability of internet-based educational technology with data being reported as means and standard deviation (see Table 16). Respondents were asked the statement, "I watch others use internet-based educational technology to see how it is used for instruction," the average was $3.72(S D=.92)$. When given the statement, "Others observe me using internetbased educational technology for my instruction," the average was $3.34(S D=.87)$.

Table 16

Averages of observability relating to internet-based educational technology

I watch others use internet-based educational technology to see how it is used for instruction
$M$

3.72

$S D$

3.34

Others observe me using internetbased educational technology for my instruction

Note. $1.00-1.59=$ Strongly Disagree, $1.60-2.59=$ Disagree, $2.60-3.59=$ Neither Agree nor Disagree, $3.60-4.59=$ Agree, and 4.60 - 5.00 = Strongly agree 
Respondents were asked to rank how they best became aware of internet-based educational technology with five options (see Table 17). Respondents ranked social media; $16 \%$ $(f=5)$ very high, $13 \%(f=4)$ high, $36 \%(f=11)$ medium, $3 \%(f=1)$ low, and $32 \%(f=10)$ very low. Respondents ranked fellow agricultural educators; $26 \%(f=8)$ very high, $55 \%(f=17$ high, and $19 \%(f=4)$ medium. Respondents ranked colleagues in your school; $58 \%(f=18)$ very high, 19\% $(f=6)$ high, 16\% $(f=5)$ medium, and 7\% $(f=2)$ low. Respondents ranked advertisements; 10\% $(f=3)$ high, $23 \%(f=8)$ medium, 61\% $(f=19)$ low, and 7\% $(f=2)$ very low. Respondents ranked News stations; 3\% $(f=1)$ high, $7 \%(f=2)$ medium, $29 \%(f=9)$ low, and $61 \%(f=19)$ very low 
Table 17

Ranking of how educators best became aware of internet-based educational technology

\begin{tabular}{|c|c|c|c|c|c|c|c|c|c|c|}
\hline & \multicolumn{2}{|c|}{ Very High } & \multicolumn{2}{|c|}{ High } & \multicolumn{2}{|c|}{ Medium } & \multicolumn{2}{|c|}{ Low } & \multicolumn{2}{|c|}{ Very Low } \\
\hline & $f$ & $\%$ & $f$ & $\%$ & $f$ & $\%$ & $f$ & $\%$ & $f$ & $\%$ \\
\hline Social Media & 5 & 16.10 & 4 & 12.90 & 11 & 35.50 & 1 & 3.20 & 10 & 32.30 \\
\hline $\begin{array}{l}\text { Fellow agricultural } \\
\text { educators }\end{array}$ & 8 & 25.80 & 17 & 54.80 & 6 & 19.40 & 0 & .00 & 0 & .00 \\
\hline Colleagues in your school & 18 & 58.10 & 6 & 19.40 & 5 & 16.10 & 2 & 6.50 & 0 & .00 \\
\hline Advertisements & 0 & .00 & 3 & 9.70 & 7 & 22.60 & 19 & 61.30 & 2 & 6.50 \\
\hline News stations & 0 & .00 & 1 & 3.20 & 2 & 6.50 & 9 & 29.00 & 19 & 61.30 \\
\hline
\end{tabular}

Respondents were asked a question about their decision to adopt internet-based educational technology for classroom instruction (see Table 18). 31\% $(f=10)$ responded with personal preference, $13 \%(f=4)$ responded with a collective decision among fellow agricultural educators, and 56\% $(f=18)$ responded with administrative and state department requirements. 
Table 18

Decision to adopt internet-based educational technology for classroom instruction

\begin{tabular}{lcc}
\hline & $f$ & $\%$ \\
\hline Personal Preference & 10 & 31.30 \\
& 4 & 12.50 \\
$\begin{array}{l}\text { Collective decision among fellow } \\
\text { agricultural educators }\end{array}$ & & \\
Administrative/State department requirements & 18 & 56.30 \\
\hline
\end{tabular}

Respondents were asked to identify barriers they have encountered while implementing internet-based educational technology for classroom instruction (see Table 19). When given the statement, "Student access to internet while working from home," the average was 3.06 ( $S D=$ .84). Respondents rated the statement, "Time to develop lessons with the technology," the average was $3.03(S D=.78)$. When given the statement, "Costs of implementing the technology," the average was $2.38(S D=.71)$. Respondents rated, "Availability of classroom resources," an average of $2.31(S D=.78)$. When given the statement, "Administrative support," the average was $1.75(S D=.76)$.

Table 19

Barriers to implementing internet-based educational technology for classroom instruction

$M \quad S D$

Student access to internet while working from home

Time to develop lessons with the technology

Costs of implementing the technology 
Administrative support

1.75

.76

Note. $1.00-1.49=$ Not a barrier, $1.50-2.49=$ Minor barrier, $2.50-3.49=$ Moderate

barrier, and $3.50-4.00=$ Major barrier

Respondents were asked how they best learned how to use internet-based educational technology (see Table 20). When given the statement, "Colleagues in your school," the average was $3.41(S D=1.10)$. For the statement, "Students," the average was $2.91(S D=.96)$.

Respondents rated the statement, "Professional development workshops," an average of 2.88 (SD $=1.07)$. When given the statement, "Fellow agricultural educators," the average was $2.78(S D=$ $.87)$.

Table 20

How educators best learned how to use internet-based educational technology

\begin{tabular}{lcc}
\hline & $M$ & $S D$ \\
\hline Colleagues in your school & 3.41 & 1.10 \\
Students & 2.91 & .96 \\
Professional development workshops & 2.88 & 1.07 \\
Fellow agricultural educators & & .87 \\
\hline
\end{tabular}
Note. $1.00-1.49=$ Not at all, $1.50-2.49=$ Small extent, $2.50-3.49=$ Moderate extent, 3.50$4.49=$ Great extent, and 4.50 $-5.00=$ Entirely

Respondents were asked to describe their perceived innovativeness of internet-based educational technology (see Table 21). Video sharing platforms: $3 \%(f=1)$ are innovators, $25 \%$ $(f=8)$ are early adopters, $31 \%(f=10)$ are early majority, $25 \%(f=8)$ are late majority, and $16 \%$ $(f=5)$ are laggards. Search engines: $9 \%(f=3)$ are innovators, 53\% $(f=17)$ are early adopters, 
$34 \%(f=11)$ are early majority, and 3\% $(f=1)$ are late majority. Learning management systems: $9 \%(f=3)$ are innovators, $25 \%(f=8)$ are early adopters, $47 \%(f=15)$ are early majority, and $19 \%(f=6)$ are late majority. Web-based games and apps: $3 \%(f=1)$ are innovators, $25 \%(f=8)$ are early adopters, $16 \%(f=5)$ are early majority, $19 \%(f=6)$ are late majority, and $38 \%(f=12)$ are laggards. Virtual field trips: $6 \%(f=2)$ are innovators, $16 \%(f=5)$ are early adopters, $34 \%(f$ $=11)$ are early majority, $16 \%(f=6)$ are late majority, and $25 \%(f=8)$ are laggard. Video conferencing platforms: $9 \%(f=3)$ are innovators, $28 \%(f=9)$ are early adopters, $28 \%(f=9)$ are early majority, $28 \%(f=9)$ are late majority, and 6\% $(f=2)$ are laggards. AET: $16 \%(f=5)$ are innovators, $44 \%(f=14)$ are early adopters, $25 \%(f=8)$ are early majority, $6 \%(f=2)$ are late majority, and 9\% $(f=3)$ are laggards. iCEV: $13 \%(f=4)$ are innovators, $16 \%(f=5)$ are early adopters, $19 \%(f=6)$ are early majority, $22 \%(f=7)$ are late majority, and $31 \%(f=10)$ are laggards 
Table 21

Perceived adopter categories of internet-based educational technology among agricultural educators

\begin{tabular}{|c|c|c|c|c|c|c|c|c|c|c|}
\hline & \multicolumn{2}{|c|}{ Innovator } & \multicolumn{2}{|c|}{ Early Adopter } & \multicolumn{2}{|c|}{ Early Majority } & \multicolumn{2}{|c|}{ Late Majority } & \multicolumn{2}{|c|}{ Laggard } \\
\hline & $f$ & $\%$ & $f$ & $\%$ & $f$ & $\%$ & $f$ & $\%$ & $f$ & $\%$ \\
\hline Video sharing platforms & 1 & 3.10 & 8 & 25.00 & 10 & 31.30 & 8 & 25.00 & 5 & 15.60 \\
\hline Search engines & 3 & 9.40 & 17 & 53.10 & 11 & 34.40 & 1 & 3.10 & 0 & .00 \\
\hline $\begin{array}{l}\text { Learning Management } \\
\text { System }\end{array}$ & 3 & 9.40 & 8 & 25.00 & 15 & 46.90 & 6 & 18.70 & 0 & .00 \\
\hline Web-based games and Apps & 1 & 3.10 & 8 & 25.00 & 5 & 15.60 & 6 & 18.70 & 12 & 37.50 \\
\hline Virtual field trips & 2 & 6.30 & 5 & 15.60 & 11 & 34.40 & 6 & 18.70 & 8 & 25.00 \\
\hline $\begin{array}{l}\text { Video conferencing } \\
\text { platforms }\end{array}$ & 3 & 9.40 & 9 & 28.10 & 9 & 28.10 & 9 & 28.10 & 2 & 6.30 \\
\hline AET & 5 & 15.60 & 14 & 43.80 & 8 & 25.00 & 2 & 6.30 & 3 & 9.40 \\
\hline $\mathrm{iCEV}$ & 4 & 12.50 & 5 & 15.60 & 6 & 18.70 & 7 & 21.90 & 10 & 31.30 \\
\hline
\end{tabular}




\section{CHAPTER 5}

\section{Conclusions and Recommendations}

\section{Purpose of the Study}

The purpose of the study is to determine the level of adoption of West Virginia agricultural educators' usage of internet-based educational technology for instruction.

\section{Objectives}

1. Describe accessibility of internet access and resources in classrooms for internet-based educational technology.

2. Describe the frequency of internet-based educational technology used in agricultural education classrooms.

3. Identify barrier(s) agricultural educators have regarding implementing internet-based educational technology in their classrooms.

4. Determine perceptions of WV agricultural educators related to the perceived attributes of internet-based educational technology.

5. Describe level of adoption of WV agricultural educators' usage of internet-based educational technology.

\section{Summary of Findings}

The population consisted of all West Virginia agricultural educators during the 20202021 calendar school year. These consisted of educators who were working in high school, middle school, and technical settings throughout the school year. The end population for the study was 103 educators. The final response rate from the study was $31 \%$ of the total population. 
The respondents were asked to identify their demographical information. Over half of the respondents identified as male. Over eighty percent of the population worked in a high school setting during the school year. Half of the respondents classified their school district as a town and only twenty-eight percent of the population who completed the study were employed in rural areas (compared to $43.9 \%$ of the total schools in the state being in rural areas.) Half of the educators were in a one teacher program. The average years spent teaching was 14.63 , with a standard deviation of 10.20 .

Respondents were asked questions relating to their accessibility of resources to use internet-based educational technology for classroom instruction. Nearly every respondent identified they had access to the Internet to use internet-based educational technology for instruction. Every respondent identified they used internet-based educational technology for instruction. Nearly every respondent identified that they had access to resources in the classroom to use internet-based educational technology for instruction. Every respondent identified their students had access to resources in the classroom to use internet-based educational technology.

Respondents were asked a question on how often they were using internet-based educational technology for instruction. Nearly half of the respondents use video sharing platforms often for instruction. Half of the respondents use search engines often for instruction. Half of the respondents use learning management systems always for instruction. Respondents rarely use web-based games and apps for instruction. Respondents are using virtual field trips rarely and occasionally for instruction. Respondents are often using video conferencing platforms for instruction. Respondents are often using the AET for instruction, with many respondents using it always as well. Most respondents are not using iCEV for instruction. 
Respondents were asked questions on how they used internet-based educational technology for instruction. Three quarters of respondents are using video sharing platforms for introduction to a unit topic, and over half of respondents are using the platforms for lessons for units, and review of classroom material. Over three quarters of respondents are using search engines for lessons of units, and over half are using search engines for introduction to unit topics, activating strategies, and review of classroom material.

Over three quarters of respondents used learning management systems for lessons for the unit, and over half of respondents are using learning management systems for activating strategies, review of classroom material, and for assessment. Under half of the respondents use web-based games and apps for review of classroom material and a quarter of respondents are using web-based games and apps for assessment. Under half of respondents are using virtual field trips for introduction to a unit topic and lessons for a unit. Half of the respondents are using iCEV for lessons for a unit.

Respondents were asked to rate statements on the relative advantage of internet-based educational technology. Respondents were neutral with the statement that they used internetbased educational technology because it is cost efficient for instruction. Respondents agreed that internet-based educational technology fosters positive learning environment for students in the classroom. Respondents agreed that internet-based educational technology is convenient to use for instruction. Respondents agreed that internet-based educational technology improves the quality of their work.

Respondents were asked to rate statements on the compatibility of internet-based educational technology. Respondents agreed that they are willing to incorporate new methods of teaching for instruction. Respondents agreed that they have support with adopting new internet- 
based educational technology for instruction. Most respondents agreed that internet-based educational technology works well with their teaching style. On average, each statement yielded an "agree" among the population.

Respondents were asked to rate statements relating to the complexity of internet-based educational technology. Respondents disagreed that they believed internet-based educational technology was difficult to use for instruction. Respondents agreed that they believed some internet-based educational technology is easier to use than others.

Respondents were asked to rate statements relating to the trialability of internet-based educational technology. Respondents agreed that they test internet-based educational technology before using them for instruction. Respondents agreed that they are willing to seek help while testing out new internet-based educational technology for instruction. Respondents were asked to rate statements relating to the observability of internet-based educational technology. Respondents agreed that they watch others use internet-based educational technology to see how it is used for instruction. Respondents were neutral with the statement that others observe them using internet-based educational technology for instruction.

Respondents were asked a question to rank how they best became aware of internet-based educational technology. Respondents ranked responses on a scale from $1=$ Very high, to $5=$ Very Low. Respondents ranked colleagues in their school the highest on how they best became aware of internet-based educational technology. Respondents ranked fellow agricultural educators second, social media was ranked third, advertisements were ranked fourth, and news stations were ranked last among respondents on how they best became aware of internet-based educational technology. 
Respondents were asked a question on their decision to adopt internet-based educational technology for classroom instruction. Over half of the respondents reported that administrative and state department requirements led to their decision to adopt internet-based educational technology for instruction. Personal preference was the second highest response for how respondents decided to adopt internet-based educational technology. A collective decision among fellow agricultural educators was the least reported response on why respondents decided to adopt internet-based educational technology.

Respondents were asked to identify barriers they have had with implementing internetbased educational technology for instruction. Student access to the internet while working from home, and time to develop lessons with the technology are two moderate barriers respondents experience while implementing internet-based educational technology. Availability of classroom resources and cost of implementing the technology were identified to be minor barriers towards implementing internet-based educational technology. Administrative support was found to not be a barrier towards implementing internet-based educational technology for instruction.

Respondents were asked how they best learned how to use internet-based educational technology. Colleagues in the educator's schools and students were a moderate extent on how educators best learned how to use internet-based educational technology. Fellow agricultural educators and professional development workshops were also a moderate extent on how respondent's best learned how to use internet-based educational technology.

Educators were asked to describe their perceived adopter categories of various internetbased educational technology resources. Responses were varied with this question, many respondents identified as an early adopter, early majority, and late majority with video sharing platforms. Over three quarters of respondents perceived adopter categories for search engines are 
early adopter and early majority. Nearly every respondent's perceived adopter categories for learning management systems are early adopter, early majority, and late majority. Web-based games and apps had laggard as the most selected response. Three quarters of the responses with virtual field trips were early majority, late majority, and laggard. Video conferencing platforms had the same number of perceived adopters in the early adopter, early majority, and late majority categories. The AET had the most responses for innovators among internet-based educational technologies. Most of the respondents perceived adopter categories for iCEV was laggard.

\section{Conclusions and Discussion}

This study provided valuable insight on how educators in West Virginia are using internet-based educational technology for instruction and has provided some interesting conclusions. The average years employed as an agricultural educator was 14.63, with a standard deviation of 10.20. This shows that the study yielded responses from educators who may have been employed for years, and some educators who are still new to the profession. These educators who have been teaching for years may have had to adopt new technology they were not familiar with to meet changes in the profession to better help their students. Rogers (2003) states that there is no difference in age among earlier and later adopters of an innovation. The study observed $31 \%$ of the total population, however the results from this study may not be an accurate representation of the entire population due to nonresponse error.

1. Describe accessibility of internet access and resources in classrooms for internet-based educational technology.

Respondents indicated close to $100 \%$ that they had access to the internet and resources in the classroom for instruction and that they are using internet-based educational technology in the 
classroom. One respondent said they did not have internet in their classroom or resources in their classroom to use the technology. The respondent may prepare lessons using internet-based educational technology ahead of time and may have access to a computer lab where students are able to access classroom materials. One key area that may need to be addressed in the future is access to the internet in the homes of the student and educator if classes are continuing to follow a hybrid or fully remote learning environment into the next school year.

2. Describe the frequency of internet-based educational technology used in agricultural education classes.

Respondents are using internet-based educational technology for classroom instruction in some capacity, some being used more than others. Video sharing platforms, search engines, learning management systems, video conferencing platforms and the AET are the internet-based educational technologies often being used for instruction. Although not used as often for instruction, technologies such as web-based games and virtual field trips are used for instruction. Web-based games and apps, as well as virtual field trips may not be used for instruction as often, as they are supplemental classroom material and may always not be the best way to share information (Jones \& Cuthrell, 2011; McDonald \& Hannfin, 2003; Licorish et al., 2018) iCEV was reported as being the least used internet-based educational technology, however this may be due to respondents using a different resource for curriculum. Respondents should work with their colleagues in their schools as well as administration as new internet-based educational technology becomes available.

Internet-based educational technology is being used in a variety of different ways in agricultural classrooms throughout West Virginia. Video sharing platforms, search engines, and learning management systems are being used the most in different aspects. The most common 
response of how respondents used the internet-based educational technology for instruction was for lessons during a unit and for reviewing classroom material. Professional development workshops may be a valuable way to help educators find new ways to use internet-based educational technology in the classroom, as well as introducing them to new internet-based educational technology. Post-workshop evaluations should be conducted and may provide an idea of how educators have implemented the material covered in the workshop in the educator's classroom (Coley et al., 2015).

3. Identify barrier(s) agricultural educators have regarding implementing internet-based educational technology in their classrooms.

Student access to the internet while working from home and time to develop lessons with the technology were two moderate barriers respondents ind icated they experienced while using internet-based educational technology for instruction. These findings on moderate barriers in agricultural classrooms is like the findings in Williams et al. (2014). As students return to the classroom, student access to the internet while working from home should be alleviated as students may live in rural areas and have limited access to the internet. As respondents continue to use internet-based educational technology, lessons may be reused and updated as needed. Respondents may have also had to adjust their teaching style to accommodate online learning, which may have led to time to develop lessons being a barrier. Respondents reported that availability of classroom materials and costs of implementing the technology were minor barriers. Further research should be conducted to identify classroom materials educators have in their classrooms. Administrative support was not reported as a barrier respondents encountered towards implementing internet-based educational technology in classrooms. Respondents should ask for support from their administration to help overcome these barriers for instruction. 
4. Determine perceptions of WV agricultural educators related to the perceived attributes of internet-based educational technology.

The perceived attributes of internet-based educational technology were well received by the respondents. Respondents agreed for the most part that internet-based educational technology has a relative advantage for classroom instruction. In some areas of agricultural education, internet-based educational technology may not have a relative advantage over other methods of teaching instruction (conducting lessons hands-on with students may be more beneficial than in an online format.) Respondents agree that internet-based educational technology is compatible with their teaching style and they have a support system for adopting new internet-based educational technology for instruction, this support system being colleagues in their school, as well as administration.

For the most part, respondents do not believe internet-based educational technology is difficult to use for instruction, but they do agree that some are easier to use than others. Respondents may have been using some internet-based educational technology over time and may find this technology to not be as difficult to use as new internet-based educational technology they are using. Respondents like to test new internet-based educational technology and seek help with the technology before using it for instruction. Professional development workshops may prove to be a valuable resource for respondents, as it would give them the opportunity to test new internet-based educational technology and identify ways that they can best use it for instruction. Respondents like to observe others using internet-based educational technology to see how it's used for instruction, but typically do not have others observe them using it first. 
5. Describe level of adoption of WV agricultural educators' usage of internet-based educational technology.

Respondents adopted internet-based educational technology at varying degrees depending on the technology. There was inconsistency among the adopter categories based on Rogers' recommendations for each adopter category. The inconsistency between the adopter categories may be due to non-response. Future studies should be conducted to identify internet-based educational technology adoption among nonrespondents and compare these results to see if there are similarities in adoption among respondents and nonrespondents. Similar studies should also be conducted in other rural states comparing West Virginia agriculture educators' adoption to educators' in these states. There was no significant difference between early and late responders.

For most of the internet-based educational technology included in this study, respondents perceived themselves as being early adopters. Rogers (2003) identifies many differences between the early and late adopters of innovations, socioeconomic status, personality variables, and communication behavior being those variables. These factors are relevant for those respondents teaching in rural areas who may have less access to resources and support than those respondents in a more populated area. Respondents have strong interpersonal networks with colleagues in their schools and fellow agricultural educators and become more aware of internet-based educational through their interpersonal networks than through mass media channels. Over half of the respondents indicated they decided to adopt internet-based educational technology based on administrative and state requirements. As new internet-based educational technology emerges, support from school administrators and the state department may be crucial in adoption of new technology.

\section{Recommendations}


For educators:

A committee should be formed to inform the population as new internet-based educational technology becomes available that educators in West Virginia may choose to adopt. This committee should be comprised of agriculture educators in West Virginia who have integrated technology adoption for instruction, and who members of the population can use as a support system with adoption. This committee could work with the faculty at West Virginia University, as well as the state department to develop professional development workshops to work with agriculture educators in West Virginia to use internet-based educational technology as it becomes available. The committee, along with faculty at West Virginia University, and the state department should identify technology resources that agriculture educators in West Virginia have to develop these professional development workshops.

For Future Research:

This study covered a broad scope of internet-based educational technology agricultural educators in West Virginia may be using for instruction. More studies should be conducted to identify adoption of internet-based educational technology not included, like social media, and other online resources agricultural educators have. A descriptive study of preservice teachers' knowledge of technology integration can help identify areas where preservice teachers excel with technology integration for instruction, and where they may lack and need additional support. Universities may have access to the most current technology, and teacher educators can model effective integration strategies in their courses (Coley et al., 2015).

Educators have had to adapt the way they presented information to their students in response to the pandemic (Ilvari et al., 2020). A qualitative study on how agricultural educators 
in West Virginia transitioned their instruction online should be conducted to assess what worked, and what did not regarding agricultural education. A study on the self-efficacy of agriculture educators' usage of technology should be conducted to assess what skills educators have towards technology integration in their classroom instruction. 


\section{REFERENCES}

Alias, N. A. \& Zainuddin, A. M. (2005). Innovation for better teacher and learning: Adopting the learning management system. Malaysian online journal of instructional technology, 2(2), $27-40$ http://citeseerx.ist.psu.edu/viewdoc/download?doi=10.1.1.119.9362\&rep=rep1\&type=pdf

Archibald, M. M., Ambagtsheer, R. C., Casey, M. G., \& Lawless, M. (2019). Using zoom videoconferencing for qualitative data collection: perceptions and experiences of researchers and participants. International Journal of Qualitative Methods, 18(1). 1-8. https://doi.org/10.1177/1609406919874596

Ary, D., Jacobs, L. C., Sorenson, C., \& Walker, D. A. (2014). Introduction to research in education (9th ed.). Cengage Learning.

Becta. (2003). What the research says about barriers to the use of ICT in teaching. https://mirand anet.ac.uk/wp-content/uploads/2019/06/wtrs_11_ict_teaching.pdf

Boyarsky, K. (2020). What is Hybrid Learning? Here's Everything You Need to Know. Owl Labs. https://www.owllabs.com/blog/hybrid-learning

Burke, S., \& Snyder, S. (2008). YouTube: An innovative learning resource for college health education courses. International Electronic Journal of Health Education, 11, 39-46. https://files.eric.ed.gov/fulltext/EJ798652.pdf

Carutasu, G., \& Pirnau, M. (2017). Facilities and changes in the educational process when using Office365. Journal of Information Systems \& Operations Management, 29.

Coley, M. D., Warner, W. J., Stair, K. S., Flowers, J. L., \& Croom, D. B. (2015). Technology usage of Tennessee agriculture teachers. Journal of Agricultural Education, 56(3), 35-51. https://doi.org/10.5032/jae.2015.03035

Computer Hope (2020). Search Engine. https://www.computerhope.com/jargon/s/searengi.htm

Dillman, D. A., Smyth, J. D., \& Christian, L. M. (2014). Internet, phone, mail, and mixed mode surveys: The tailored design method (4th ed.). John Wiley \& Sons Inc.

Domingo, M. G., \& Garganté, A. B. (2016). Exploring the use of educational technology in primary education: Teachers' perception of mobile technology learning impacts and applications' use in the classroom. Computers in Human Behavior, 56, 21-28. https://doi.org/10.1016/j.chb.2015.11.023

Easterly III, R. G., \& Simpson, K. (2020). An examination of the curricular resources use and self-efficacy of Utah school-based agricultural education teachers: An exploratory study. Journal of Agricultural Education, 61(4), 30-45 http://doi.org/10.5032/jae.2020.04035

Federal Communications Commission. (2014). Types of Broadband Connections. https://www.fcc.gov/general/types-broadband-connections 
Gautreau, C. (2011). Motivational factors affecting the integration of a learning management system by faculty. Journal of Educators Online, 8(1). https://files.eric.ed.gov/fulltext/EJ917870.pdf

Grysiuk, M. (2018). OUT OF THE BOX: WHY ORGANIZATIONS ARE JUMPING TO OFFICE 365/ SHAREPOINT ONLINE. Information Management, 52(5), 20-24,26-27. http://www.libproxy.wvu.edu/login?url=https://www.proquest.com/docview/2117116925 ?accountid $=2837$

iCEV. (2020). Standards-aligned curriculum: Agricultural science. https://www. icevonline.com/curriculum/agricultural-science

Iivari, N., Sharma, S., \& Ventä-Olkkonen, L. (2020). Digital transformation of everyday lifeHow COVID-19 pandemic transformed the basic education of the young generation and why information management research should care?. International Journal of Information Management, 55(), 1-6. https://doi.org/10.1016/j.ijinfomgt.2020.102183

Jones, T. \& Cuthrell, K. (2011). Youtube: Educational potentials and pitfalls. Computers in the Schools, 28(1), 75-85. https://doi.org/10.1080/07380569.2011.553149

Kaden, U. (2020). COVID-19 school closure-related changes to the professional life of a K-12 teacher. Education Sciences, 10(6), 1-13. https://doi.org/10.3390/educsci10060165

Kagan, J. (2019). Video Conferencing. Investopedia. https://www.investopedia.com/terms/v/videoconferencing.asp\#: :text=Video\%20conferencing\%20is\%20a\%20technology,to\%20a\%2 0single $\% 20$ location $\% 20$ together.\&text $=$ Uses $\% 20$ for $\% 20$ video $\% 20$ conferencing $\% 20$ incl ude, deals \%2C\%20and\%20interviewing\%20job\%20candidates.

Kakoulli-Constantinou, E. (2018). Teaching in clouds: using the G Suite for Education for the delivery of two EAP courses. Journal of Teaching English for Specific and Academic Purposes, 6(2), 305-317. https://doi.org/10.22190/JTESAP1802305C

Kaplan, A. M., \& Haenlein, M. (2010). Users of the world, unite! The challenges and opportunities of Social Media. Business Horizons, 51(1), 59-68. https://d oi.org/10.1016/j.bushor.2009.09.003

Keaton, P. (2013). Common Core of Data; Table 2.-Number of operating public schools and districts, state enrollment, teacher and pupil/teacher ratio by state: School year 2012 2013. United States Department of Education, National Center for Education Statistics. https://nces.ed.gov/pubs2014/2014098.pdf

Kim, K. J., \& Bonk, C. J. (2006). The future of online teaching and learning in higher education. Educause quarterly, 29(4), 22-30. 
Klemm, E. B., \& Tuthill, G. (2003). Virtual field trips: Best practices. International Journal of Instructional Media, 30(2), 177-193.

http://www.libproxy.wvu.edu/login?url=https://www.proquest.com/scholarlyjournals/virtual-field-trips-best-practices/docview/204262556/se-2?accountid=2837

Kotrlik, J. W., \& Redmann, D. H. (2009). Technology Adoption for Use in Instruction by Second ary Technology Education Teachers. Journal of Technology Education, 21(1), 4459. https://vtechworks.lib.vt.edu/bitstream/handle/10919/8443/kotrlik.pdf? sequence=1

Langville, A. N., \& Meyer, C. D. (2011). Google's PageRank and beyond: The science of search engine rankings. New Jersey: Princeton University Press

Levin, D., \& Arafeh, S. (2002). The digital disconnect: The widening gap between internetsavvy students and their schools. Pew Internet \& American Life Project.

Licorish, S. A., Owen, H. E., Daniel, B., \& George, J. L. (2018). Students' perception of Kahoot!'s influence on teaching and learning. Research and Practice in Technology Enhanced Learning, 13(1), 1-23. https://doi.org/10.1186/s41039-018-0078-8

McDonald, K. K., \& Hannafin, R. D. (2003). Using web-based computer games to meet the demands of today's high-stakes testing: A mixed method inquiry. Journal of Research on Technology in Education, 35(4), 459-472. https://doi.org/10.1080/15391523.2003.10782396

Mowery, D. C., \& Simcoe, T. (2002). Is the Internet a US invention? - an economic and technological history of computer networking. Research Policy, 31(8-9), 1369-1387. https://d oi.org/10.1016/S0048-7333(02)00069-0

Nast, P. (n.d.). YouTube for Educators. National Education Association. http://www.nea.org/tools/lessons/50803.htm

National Association of Agricultural Educators. (2020). What is Agricultural Education. https://www.naae.org/whatisaged/

Our Story. (2021). AET. https://www.theaet.com/story

Phipps, L. J., \& Osborne, E. W. (1988). Handbook on agricultural education in public schools. Danville, IL: Interstate.

Plump, CM, \& LaRosa, J. (2017). Using Kahoot! in the classroom to create engagement and active learning: a gamebased technology solution for eLearning novices. Management Teaching Review, 2(2), 151-158. https://doi.org/10.1177/2379298116689783

Ramsey, J. W., \& Edwards, M. C. (2011). Entry-Level Technical Skills that Agricultural Industry Experts Expected Students to Learn through Their Supervised Agricultural Experiences: A Modified Delphi Study. Journal of Agricultural Education, 52(2), 82-94. https://doi.org/ 10.5032/jae.2011.02082 
Ray, K. (2020). What is Remote Learning?. Tech \& Learning: Tools \& Ideas to Transform Education. https://www.techlearning.com/how-to/what-is-remote-learning

Recker, M. M., Dorward, J., \& Nelson, L. M. (2004). Discovery and use of online learning resources: Case study findings. Journal of Educational Technology \& Society, 7(2), 93104. https://www.jstor.org/stable/jeductechsoci.7.2.93

Rogers, E. (2003). Diffusion of innovations (5th ed.). New York: Free Press.

Schoology. (2018). Schoology vs. Google Classroom: 8 common questions answered. https://www.schoology.com/blog/schoology-vs-google-classroom-8-common-questionsanswered\#: :text=Schoology\%20is\%20a\%20scalable\%20district,collaborative $\% 20$ teachi ng\%20and\%20learning\%20environments.

Seymour, T., Frantsvog, D., \& Kumar, S. (2011). History Of Search Engines. International Journal of Management \& Information Systems (IJMIS), 15(4), 47-58. https://doi.org/10.19030/ijmis.v15i4.5799

Smith, H. E., Stair, K.S., Blackburn, J. J., \& Easley, M. (2018). Is there an app for that? Describing smartphone availability and educational technology adoption level of Louisiana school-based agricultural educators. Journal of Agricultural Education, 59(1), 238-254. https://doi.org/10.5032/jae.2018.01238

Tavakol, M., \& Dennick, R. (2011). Making sense of Cronbach's alpha. International journal of medical education, 2, 53-55. https://doi.org/10.5116/ijme.4dfb.8dfd

TeacherTube. (2020). About us. https://www.teachertube.com/about-us

Terantino, J. M. (2011). Emerging technologies YouTube for foreign languages: You have to see this video. Language Learning and Technology, 15(1), 10-16. https://digitalcommons.kennesaw.edu/cgi/viewcontent.cgi?article=2616\&context=facpub S

Tuthill, G., \& Klemm, E. B. (2002). Virtual field trips: Alternatives to actual field trips. International journal of instructional media, 29(4), 453-468. https://wwwv.libproxy.wvu.edu/login?url=https://www.proquest .com/scholarlyjournals/virtual-field-trips-alternatives-actual/docview/204317859/se-2 ?accountid=2837

United States Department of Education. (n.d.). Use of Technology in Teaching and Learning. https://www.ed.gov/oii-news/use-technology-teaching-andlearning\#: :text=Used \%20to\%20support\%20both\%20teaching,skills\%3B\%20increases\% 20student $\% 20$ engagement $\% 20$ and

Williams, M. R., Warner, W. J., Flowers, J. L, \& Croom, D. B. (2014). Accessibility and Usage of Technology by North Carolina Agriculture Teachers. Journal of Agricultural Education, 55(4), 191-206. https://doi.org/10.5032/jae.2014.04191

Williams, M. R., Warner, W. J., Flowers, J. L., \& Croom, D.B. (2014). Teaching with Technology: North Carolina Agriculture Teachers' Knowledge Acquisition, Attitudes, 
and Identified Barriers. Journal of Agricultural Education, 55(5), 1-15.

https://doi.org/10.5032/jae.2014.05001

Yadav, A., \& Berges, M. (2019). Computer science ped agogical content knowledge:

Characterizing teacher performance. ACM Transactions on Computing Education (TOCE), 19(3), 1-24. https://doi.org/10.1145/3303770

Zanetis, J. (2010). The Beginner's Guide to Interactive Virtual Field Trips. Learning \& Leading with Technology, 37(6), 20-23. https://files.eric.ed.gov/fulltext/EJ886387.pdf

Zoom Video Communications Inc. (2016). Security guide. Zoom Video Communications Inc. https://d24cgw3 uvb9a9h.cloudfront.net/static/81625/doc/Zoom-Security-WhitePaper.pdf 
APPENDIX A

Cover Letter Email 
Good afternoon teachers,

I would like to welcome you to a survey opportunity that will examine your level of adoption of internet-based educational technology for classroom instruction.

The survey will take approximately 10 minutes to complete. Please answer each question to the best of your ability. Your participation is $100 \%$ voluntary, but greatly appreciated.

The Institutional Review Board at West Virginia University has approved this study.

The survey will open on February 2nd, and will remain open until March 2nd at 5 p.m. EST.

If you have any questions about the survey, please feel free to reach out to myself or Dr. Rachel Hendrix at rachel.hendrix@ mail.wvu.edu. Please click the link below to access the survey.

Click here to begin the survey

Thank you all for your consideration,

Travis D. Veach 
APPENDIX B

\section{Instrument}




\section{Thesis survey}

\section{Start of Block: Welcome}

Welcome to this survey, which will examine West Virginia agricultural educators' level of adoption of internet-based education technology using Rogers Diffusion of Innovations Theory. This survey will take approximately 10 minutes to complete. If you have any questions, please contact Travis Veach via email attdveach@mix.wvu.edu. It is recommended to complete this survey on a laptop or desktop computer as a few questions contain multiple parts and this allows for the entire question to be viewed at once. Responses will be protected, and confidentiality will be maintained. To proceed, click the arrow at the bottom right of your screen, you may also return to any questions via the back arrow at the bottom left of your screen. Thank you for your participation in this survey.

\section{End of Block: Welcome}

\section{Start of Block: Introductory questions}

Q1 Do you have Internet access for classroom instruction?
Yes (1)

No (2)

Q2 Do you use internet-based educational technology (Google, Office 365, etc.) for classroom instruction?

\section{Yes (1)}

No (2) 
Q3 Do you, as the instructor, have access to resources (work computer/laptop) to use internetbased educational technology for instruction?

\section{Yes (1)}

No (2)

Q4 Do your students have resources (laptops, tablets, phones, etc.) to use internet-based educational technology for instruction?

Yes (1)

No (2)

\section{End of Block: Introductory questions}

Start of Block: Frequency of intermet-based educational technology 
Q5 Please indicate how often you use the following internet-based educational technologies for instruction.

\begin{tabular}{|c|c|c|c|c|c|}
\hline & Never (1) & Rarely (2) & $\begin{array}{c}\text { Occasionally } \\
\text { (3) }\end{array}$ & Often (4) & Always (5) \\
\hline $\begin{array}{l}\text { Video sharing } \\
\text { platforms } \\
\text { (YouTube, } \\
\text { TeacherTube, } \\
\text { etc.) (1) }\end{array}$ & $\bigcirc$ & 0 & 0 & 0 & 0 \\
\hline $\begin{array}{c}\text { Search } \\
\text { Engines } \\
\text { (Google, } \\
\text { Yahoo, etc.) } \\
\text { (2) }\end{array}$ & $\bigcirc$ & 0 & 0 & 0 & 0 \\
\hline $\begin{array}{l}\text { Learning } \\
\text { Management } \\
\text { Systems } \\
\text { (Schoology, }\end{array}$ & & & & & \\
\hline $\begin{array}{l}\text { Office } 365 \text {, } \\
\text { Google } \\
\text { Workspace, } \\
\text { etc.) (3) }\end{array}$ & O & 0 & 0 & 0 & 0 \\
\hline $\begin{array}{c}\text { Web-based } \\
\text { games and } \\
\text { Apps (4) }\end{array}$ & O & $\bigcirc$ & $\bigcirc$ & 0 & $\bigcirc$ \\
\hline $\begin{array}{l}\text { Virtual field } \\
\text { trips (5) }\end{array}$ & O & 0 & 0 & $\bigcirc$ & $\bigcirc$ \\
\hline $\begin{array}{c}\text { Video } \\
\text { conferencing } \\
\text { platforms } \\
\text { (Zoom, }\end{array}$ & & & & & \\
\hline $\begin{array}{c}\text { Microsoft } \\
\text { Teams, } \\
\text { Google Meet) } \\
\text { (6) }\end{array}$ & $\bigcirc$ & 0 & 0 & 0 & O \\
\hline The AET (7) & $\bigcirc$ & $\bigcirc$ & $\bigcirc$ & 0 & 0 \\
\hline iCEV (8) & 0 & 0 & 0 & $\bigcirc$ & 0 \\
\hline
\end{tabular}


Q6 Please select all responses that describe how you use video sharing platforms for classroom instruction.

Introduction to a unit topic (1)

Activating strategies (2)

Lessons for the unit (3)

Review of classroom material (4)

Formative/Summative assessment (5)

I do not use this internet-based educational technology for classroom instruction (6) 
Q7 Please select all responses that describe how you use search engines for classroom instruction.

$\square$ Introduction to a unit topic (1)

$\square$ Activating strategies (2)

Lessons for the unit (3)

Review of classroom material (4)

Formative/Summative assessment (5)

I do not use this internet-based educational technology for classroom instruction (6)

Q8 Please select all responses that describe how you use Learning Management Systems for classroom instruction.

$\square$ Introduction to a unit topic (1)

$\square$ Activating strategies (2)

Lessons for the unit (3)

Review of classroom material (4)

Formative/Summative assessment (5)

I do not use this internet-based educational technology for classroom instruction (6) 
Q9 Please select all responses that describe how you use web-based games and apps for classroom instruction.

$\square$ Introduction to a unit topic (1)

Activating strategies (2)

Lessons for the unit (3)

Review of classroom material (4)

Formative/Summative assessment (5)

I do not use this internet-based educational technology for classroom instruction

(6) 
Q10 Please select all responses that describe how you use virtual field trips for classroom instruction.

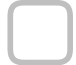

Introduction to a unit topic (1)

Activating strategies (2)

Lessons for the unit (3)

Review of classroom material (4)

Formative/Summative assessment (5)

I do not use this internet-based educational technology for classroom instruction

(6)

Q11 Please select all responses that describe how you use iCEV for classroom instruction.

Introduction to a unit topic (1)

Activating Strategies (2)

Lessons for the unit (3)

Review of classroom material (4)

Formative/Summative assessment (5)

I do not use this internet-based educational technology for classroom instruction (6) 
Start of Block: Factors influencing ROA 
Q12 For the following statements, please rate your agreement or disagreement of relative advantage relating to internet-based educational technology.

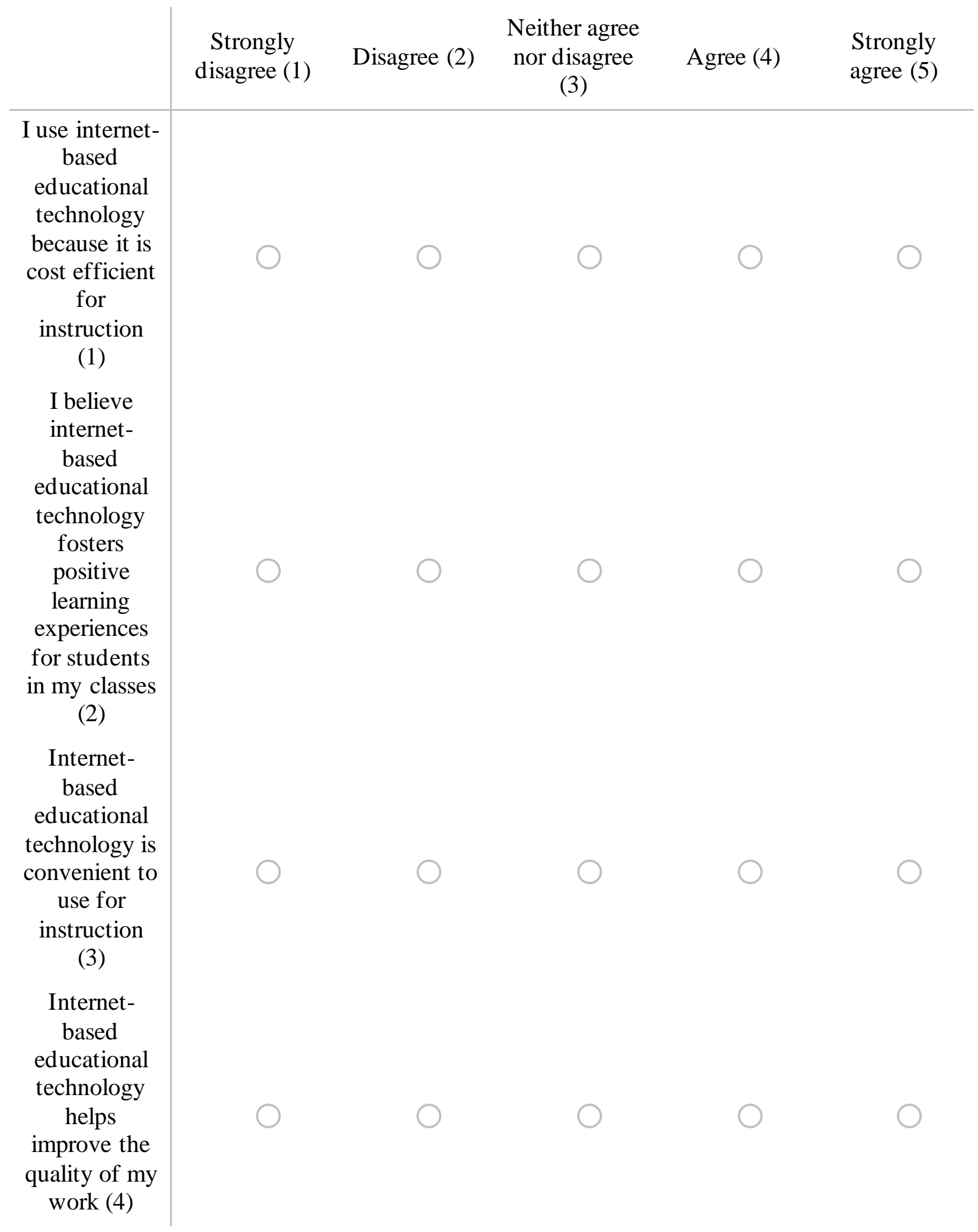


Q13 For the following statements, please rate your agreement or disagreement of compatibility relating to internet-based educational technology.

\begin{tabular}{|c|c|c|c|c|c|}
\hline & $\begin{array}{c}\text { Strongly } \\
\text { disagree (1) }\end{array}$ & Disagree (2) & $\begin{array}{c}\text { Neither agree } \\
\text { nor disagree } \\
\text { (3) }\end{array}$ & Agree (4) & $\begin{array}{l}\text { Strongly } \\
\text { agree (5) }\end{array}$ \\
\hline $\begin{array}{l}\text { I am willing } \\
\text { to incorporate } \\
\text { new methods } \\
\text { of teaching } \\
\text { for } \\
\text { instruction } \\
\text { (1) }\end{array}$ & & & & & \\
\hline $\begin{array}{c}\text { I have } \\
\text { support with } \\
\text { adopting new } \\
\text { internet- } \\
\text { based } \\
\text { educational } \\
\text { technology } \\
\text { for my } \\
\text { instruction } \\
\text { (2) }\end{array}$ & & & & ( & \\
\hline $\begin{array}{c}\text { Internet- } \\
\text { based } \\
\text { educational } \\
\text { technology } \\
\text { works well } \\
\text { with my } \\
\text { teaching style } \\
\text { (3) }\end{array}$ & & & & $\cap$ & \\
\hline
\end{tabular}


Q14 For the following statements, please rate your agreement or disagreement of complexity relating to internet-based educational technology.

\begin{tabular}{|c|c|c|c|c|c|}
\hline & $\begin{array}{c}\text { Strongly } \\
\text { disagree (1) }\end{array}$ & Disagree (2) & $\begin{array}{c}\text { Neither agree } \\
\text { nor disagree } \\
\text { (3) }\end{array}$ & Agree (4) & $\begin{array}{l}\text { Strongly } \\
\text { agree (5) }\end{array}$ \\
\hline $\begin{array}{l}\text { I believe } \\
\text { internet- } \\
\text { based } \\
\text { educational } \\
\text { technology is } \\
\text { difficult to } \\
\text { use for } \\
\text { instruction } \\
\text { (1) }\end{array}$ & & 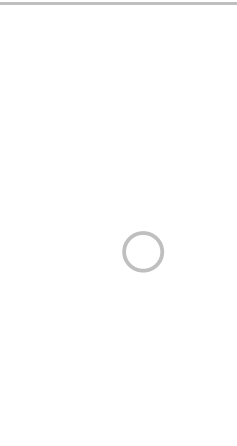 & & & ( \\
\hline $\begin{array}{c}\text { I believe } \\
\text { some } \\
\text { internet- } \\
\text { based } \\
\text { educational } \\
\text { technology is } \\
\text { easier to use } \\
\text { than others } \\
\text { (2) }\end{array}$ & & $\circ$ & & & \\
\hline
\end{tabular}


Q15 For the following statements, please rate your agreement or disagreement of trialability relating to internet-based educational technology.

\begin{tabular}{|c|c|c|c|c|c|}
\hline & $\begin{array}{c}\text { Strongly } \\
\text { disagree (1) }\end{array}$ & Disagree (2) & $\begin{array}{c}\text { Neither agree } \\
\text { nor disagree } \\
\text { (3) }\end{array}$ & Agree (4) & $\begin{array}{l}\text { Strongly } \\
\text { agree (5) }\end{array}$ \\
\hline $\begin{array}{l}\text { I test internet- } \\
\text { based } \\
\text { educational } \\
\text { technology } \\
\text { resources out } \\
\text { before using } \\
\text { them for } \\
\text { instruction } \\
\text { (1) }\end{array}$ & & & & & 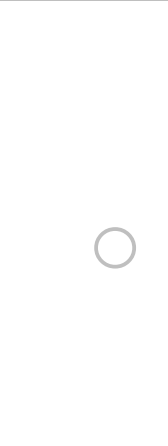 \\
\hline $\begin{array}{l}\text { I am willing } \\
\text { to seek help } \\
\text { while testing } \\
\text { out new } \\
\text { internet- } \\
\text { based } \\
\text { educational } \\
\text { technology } \\
\text { resources for } \\
\text { instruction } \\
\text { (2) }\end{array}$ & ? & $\cap$ & & & \\
\hline
\end{tabular}


Q16 For the following statements, please rate your agreement or disagreement of observability relating to internet-based educational technology.

\begin{tabular}{|c|c|c|c|c|c|}
\hline & $\begin{array}{c}\text { Strongly } \\
\text { disagree (1) }\end{array}$ & Disagree (2) & $\begin{array}{c}\text { Neither agree } \\
\text { nor disagree } \\
\text { (3) }\end{array}$ & Agree (4) & $\begin{array}{l}\text { Strongly } \\
\text { agree (5) }\end{array}$ \\
\hline $\begin{array}{c}\text { I watch } \\
\text { others use } \\
\text { internet- } \\
\text { based } \\
\text { educational } \\
\text { technology to } \\
\text { see how it is } \\
\text { used for } \\
\text { instruction } \\
\text { (1) }\end{array}$ & D & 1 & & & $\bigcirc$ \\
\hline $\begin{array}{c}\text { Others } \\
\text { observe me } \\
\text { using } \\
\text { internet- } \\
\text { based } \\
\text { educational } \\
\text { technology } \\
\text { for my } \\
\text { instruction } \\
\text { (2) }\end{array}$ & 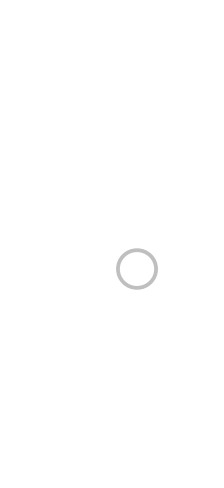 & ) & 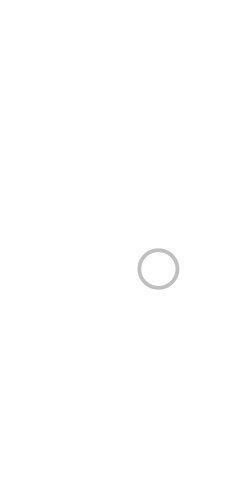 & 0 & $\cap$ \\
\hline
\end{tabular}

Q17 Please rank how you best became aware of internet-based educational technology with 1 being the highest and 5 being the lowest.

Social media (1)

Fellow agricultural educators (2)

Colleagues in your school (3)

Advertisements (4)

News stations (5) 
Q18 How would you best describe your decision to adopt internet-based educational technology?

Personal Preference (1)

Collective decision among fellow agricultural educators (2)

Administrative/State department requirements (3)

Q19 Identify the impact the following barriers have had on your integration of internet-based educational technology.

Not a barrier (1)

Minor barrier Moderate barrier

Major barrier (4)

\section{Student access to \\ internet while \\ working from \\ home (1) \\ Availability of classroom \\ resources (2) \\ Time to develop lessons with the technology (3) \\ Administrative support (4) \\ Costs of implementing the technology}

(5) 
Q20 Please describe to what extent the following statements have helped you best learn how to use internet-based educational technology for instruction.

\begin{tabular}{|c|c|c|c|c|c|}
\hline & Not at all (1) & $\begin{array}{l}\text { Small extent } \\
\text { (2) }\end{array}$ & $\begin{array}{l}\text { Moderate } \\
\text { extent (3) }\end{array}$ & $\begin{array}{c}\text { Great extent } \\
\text { (4) }\end{array}$ & Entirely (5) \\
\hline $\begin{array}{l}\text { Fellow } \\
\text { agricultural } \\
\text { educators (2) }\end{array}$ & $\bigcirc$ & 0 & 0 & ○ & ○ \\
\hline $\begin{array}{l}\text { Colleagues in } \\
\text { your schools } \\
\text { (3) }\end{array}$ & O & 0 & O & $\bigcirc$ & $\bigcirc$ \\
\hline Students (4) & $\bigcirc$ & $\bigcirc$ & $\bigcirc$ & O & O \\
\hline $\begin{array}{c}\text { Professional } \\
\text { development } \\
\text { workshops } \\
\text { (5) }\end{array}$ & O & O & O & $\bigcirc$ & $\bigcirc$ \\
\hline
\end{tabular}

\section{End of Block: Factors influencing ROA}

Start of Block: Innovativeness of WV educators relating to the internet-based educational tech. 
Q21 For each of the following internet-based educational technologies, please indicate your perceived adopter category.

\begin{tabular}{|c|c|c|c|c|c|}
\hline & Innovator (1) & $\begin{array}{c}\text { Early adopter } \\
\text { (2) }\end{array}$ & $\begin{array}{c}\text { Early } \\
\text { majority (3) }\end{array}$ & $\begin{array}{c}\text { Late majority } \\
\text { (4) }\end{array}$ & Laggard (5) \\
\hline $\begin{array}{l}\text { Video sharing } \\
\text { platforms } \\
\text { (YouTube, } \\
\text { TeacherTube, } \\
\text { etc.) (1) }\end{array}$ & 0 & 0 & O & 0 & 0 \\
\hline $\begin{array}{c}\text { Search } \\
\text { Engines } \\
\text { (Google, } \\
\text { Yahoo, etc.) } \\
(2)\end{array}$ & 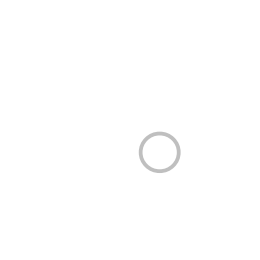 & $\bigcirc$ & O & $\bigcirc$ & $\bigcirc$ \\
\hline $\begin{array}{l}\text { Office } 365 \& \\
\text { Google } \\
\text { Workspace } \\
\text { (3) }\end{array}$ & O & $\bigcirc$ & 0 & $\bigcirc$ & $\bigcirc$ \\
\hline $\begin{array}{c}\text { Web-based } \\
\text { games and } \\
\text { Apps (4) }\end{array}$ & $\bigcirc$ & $\bigcirc$ & $\mathrm{O}$ & 0 & 0 \\
\hline $\begin{array}{l}\text { Virtual field } \\
\text { trips (5) }\end{array}$ & O & 0 & $\mathrm{O}$ & O & 0 \\
\hline $\begin{array}{c}\text { Video } \\
\text { conferencing } \\
\text { platforms } \\
\text { (Zoom, } \\
\text { Microsoft } \\
\text { Teams, } \\
\text { Google Meet) } \\
\text { (6) }\end{array}$ & $\bigcirc$ & 0 & $\bigcirc$ & $\bigcirc$ & 0 \\
\hline The AET (7) & 0 & 0 & 0 & 0 & 0 \\
\hline $\operatorname{iCEV}(8)$ & $\bigcirc$ & 0 & 0 & 0 & 0 \\
\hline
\end{tabular}


Q22 How many years have you been employed as an agricultural educator as of the 2020-2021 calendar school year?

Please use the slider to answer the question.

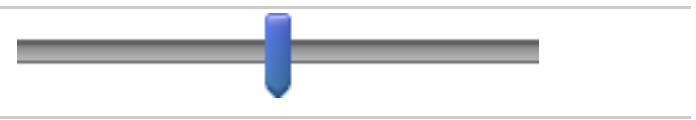

Q23 What is your gender?

Male (1)

Female (2)

Prefer not to answer (3)

Q24 What type of school are you currently employed at?

High school (1)

Middle school (2)

Technical center (3)

Both high school and middle school (4) 
Q25 What is the classification of your school district?

Rural (less than 1,000 people living within close proximity to the school) (1)

Town (between 1,000-10,000 people living in or around the town) (2)

Suburban (25,000-30,000 people living in or around school district) (3)

Urban (50,000+ people living in or around school district) (4)

Q26 How many teachers are in your program?

One teacher (1)

Two teachers (2)

Three teachers (3)

Four teachers (4)

\section{End of Block: Demographics}

\section{Start of Block: Block 6}

Thank you again for your participation in this survey, which examined West Virginia agricultural educators' adoption of internet-based educational technology. If you have any questions about how your responses will be used, please email Travis Veach at tdveach@mix.wvu.edu and I will be happy to answer them. If you would like to change any of your responses, you may use the back arrow to do so. If you are ready to submit your responses, use the arrow at the bottom right of your screen to exit the survey. 
APPENDIX C

Follow-up Reminder Emails 
Good afternoon agriculture educators,

This is the first reminder email for a survey opportunity to examine your level of adoption of internet-based educational technology.

If you have already completed the survey, your responses have been saved and are highly appreciated.

The survey will be open for two more weeks, closing on March 2nd at $5 \mathrm{pm}$. Below is a link to the survey.

Click here to begin the survey

Thank you all for all you do for our students!

Travis D. Veach

Good afternoon teachers,

This will be the final email reminder for a thesis survey opportunity to examine your level of adoption of internet-based educational technology for classroom instruction. The survey will close March 2nd at $5 \mathrm{pm}$. Below is a link to access the survey.

Click here to begin the survey

Thank you again to those who have completed the survey. If you have any questions, please feel free to contact me at any time at tdveach@mix.wvu.edu.

Sincerely,

Travis Veach 


\section{APPENDIX D}

Thank you Email 
Good after teachers,

Thank you for your participation in this survey. The results have been gathered and the survey has concluded. We greatly appreciate your participation in this study. The results of the study will be beneficial to agricultural educators in West Virginia schools.

If you have any questions regarding this study, please feel free to reach out to me at tdveach@mix.wvu.edu or by phone at 304-813-7172. Again, thank you for completing the survey and helping me with my research.

Sincerely,

Travis D. Veach 